\title{
Current insights into the mechanisms and management of infection stones
}

\section{Authors: Erika J. Espinosa-Ortiz, Brian H. Eisner, Dirk Lange, and Robin Gerlach}

The final publication is available at Springer via https://dx.doi.org/10.1038/s41585-018-0120-z.

Espinosa-Ortiz, Erika J., Brian H. Eisner, Dirk Lange, and Robin Gerlach, "Current insights into the mechanisms and management of infection stones," Nature Reviews Urology, November 2018, 16: 35-53. doi: 10.1038/s41585-018-0120-z. 


\title{
Current insights into the mechanisms and management of infection stones
}

\author{
Erika J. Espinosa-Ortiz ${ }^{1,2}$, Brian H. Eisner ${ }^{3}$, Dirk Lange ${ }^{4 *}$ and Robin Gerlach $\mathbb{1}^{1,2 *}$ \\ Abstract | Infection stones are complex aggregates of crystals amalgamated in an organic matrix \\ that are strictly associated with urinary tract infections. The management of patients who form \\ infection stones is challenging owing to the complexity of the calculi and high recurrence rates. \\ The formation of infection stones is a multifactorial process that can be driven by urine chemistry, \\ the urine microenvironment, the presence of modulator substances in urine, associations with \\ bacteria, and the development of biofilms. Despite decades of investigation, the mechanisms of \\ infection stone formation are still poorly understood. A mechanistic understanding of the \\ formation and growth of infection stones - including the role of organics in the stone matrix, \\ microorganisms, and biofilms in stone formation and their effect on stone characteristics - and \\ the medical implications of these insights might be crucial for the development of improved \\ treatments. Tools and approaches used in various disciplines (for example, engineering, chemistry, \\ mineralogy, and microbiology) can be applied to further understand the microorganism-mineral \\ interactions that lead to infection stone formation. Thus, the use of integrated multidisciplinary \\ approaches is imperative to improve the diagnosis, prevention, and treatment of infection stones.
}

Supersaturation The presence of a solute at a higher concentration in a solution than that of its own solubility.

\footnotetext{
'Center for Biofilm Engineering, Montana State University, Bozeman, MT, USA.

${ }^{2}$ Chemical \& Biological Engineering, College of Engineering, Montana State University, Bozeman, MT, USA.

${ }^{3}$ Department of Urology, Massachusetts General Hospital, Harvard Medical School, Boston, MA, USA.

${ }^{4}$ The Stone Centre at Vancouver General Hospital, Department of Urologic Sciences, University of British Columbia, Jack Bell Research Centre, Vancouver, British Columbia, Canada *e-mail:dirk.lange@ubc.ca; robin_g@montana.edu https://doi.org/10.1038/ s41585-018-0120-z
}

Urolithiasis, a condition of urinary stone (calculi) formation in the bladder or urinary tract, is a common disease in worldwide primary care practice that results in considerable morbidity to patients and poses a substantial financial burden on health-care systems. In the USA, the financial cost of urolithiasis has been estimated to exceed US $\$ 5$ billion annually, including both direct treatment costs and indirect costs related to the loss of labour productivity $^{1,2}$. In 2009, 1.3 million emergency department visits related to kidney stone disease were reported ${ }^{3}$. The incidence and prevalence of kidney stones (nephrolithiasis) have increased globally over the past few decades ${ }^{4}$, presumably owing to changes in lifestyle, dietary habits, and the climate ${ }^{5,6}$. Despite a substantial amount of research focused on the genetics, pathophysiology, diagnosis, prevention, and treatment of urolithiasis, the overall incidence has not decreased and urolithiasis remains a major global health-care issue.

Urinary stones are complex aggregates of crystals that can also contain organic compounds (including proteins, lipids, and polysaccharides) and cellular debris (which is not an organic compound per se, but is comprised of organic waste products left over after a cell dies). Urinary stones differ in their composition, causes of development, and corresponding treatment and prevention options ${ }^{7-10}$ (TABLE 1). In brief, urinary stones can be classified according to the composition of their inorganic fraction (which comprises the bulk of the material) into calcium stones, uric acid stones, struvite stones, cystine stones, or drug-induced stones.

Infection stones are a particular subset of urinary stones that are mainly comprised of struvite combined with calcium phosphate (carbapatite) and/or calcium oxalate and that seem to be strictly associated with urinary tract infections (UTIs) ${ }^{11}$. Infection stone formers are one of the most challenging populations of patients with stone disease owing to the complexity of the calculi and the high rates of recurrence ${ }^{11}$. The incidence and prevalence, mineral composition, and formation of infection stones is a multifactorial process determined by urine chemistry (high solute concentrations in urine that lead to supersaturation), the urine microenvironment ( $\mathrm{pH}$ and ionic strength), the presence of substances that promote or inhibit crystallization and aggregation (such as organic molecules) in urine, and the association with bacteria resulting in the development of biofilms (which can, in turn, modify the urinary milieu and consequently influence stone formation $)^{12-16}$.

In this Review, we discuss the current understanding of infection stones, including the mechanisms involved in stone formation and growth, the role of organics in the stone matrix, microorganisms, and biofilms in stone formation and their effect on stone characteristics, as well as the medical implications of these insights and management strategies. Tools and approaches used in various disciplines (for example, engineering, chemistry, 


\section{Key points}

- Urine chemistry has a key role in infection stone formation and is determined by the saturation conditions, $\mathrm{pH}$, and the presence of modulators of crystallization and aggregation in the urine.

- Organic substances associated with infection stones influence their physical characteristics (for example, hardness) and could also be involved in stone formation.

- Struvite stones are associated with urinary tract infections and are formed as a result of biomineralization by urea-hydrolysing microorganisms.

- Positive stone cultures suggest the association of bacteria with calcium-based stones; however, the role of bacteria (active or passive) in the lithogenesis of calcium-based stones requires further examination.

- The development of microbial biofilms complicates renal conditions and treatments; biofilm mechanical stability and resistance to treatment is increased by the biomineralization process.

- Infection stone management strategies should rely on the proper identification and characterization of stones and an understanding of stone formation, stone microbiology, and the influence of biofilms on stone characteristics.

\section{Biofilms}

Microorganisms attached to a surface and embedded in an extracellular polymeric substance matrix. mineralogy, and microbiology) are presented, which can be applied to further understand the microorganismmineral interactions that can lead to infection stone formation. Finally, we highlight the importance of using integrated multidisciplinary approaches in the diagnosis, prevention, and treatment of infection stones.

\section{Types of urinary stones}

Calcium stones (including calcium oxalate and calcium phosphate stones) are the most common type of urinary stones among the general population, with a prevalence of $70-80 \%$ in industrialized countries ${ }^{17}$ (TABLE 1). Approximately $80 \%$ of calcium stones contain calcium oxalate as the predominant component ${ }^{17}$, which is commonly admixed with calcium phosphate. Stones predominantly comprised of calcium phosphate are infrequently found ${ }^{18}$. Lithogenesis of calcium-based stones is associated with metabolic abnormalities in stone formers, including hypercalciuria (excessive excretion of urinary calcium $)^{19}$, hypocitraturia (low excretion of urinary citrate, which forms complexes with calcium and inhibits its crystal growth and aggregation $)^{20}$, and hyperoxaluria (excessive excretion of urinary oxalate) ${ }^{21}$. Risk factors for calcium oxalate stones include excessive urinary concentrations of oxalate and calcium ${ }^{22}$. Lithogenesis of calcium phosphate stones is dependent on the urinary $\mathrm{pH}^{23,24}$ and calcium concentration ${ }^{25}$; given that calcium phosphate solubility decreases under alkaline conditions, the excessive excretion of urinary calcium combined with an alkaline urinary $\mathrm{pH}(>6.0)$ favours the formation of calcium phosphate stones ${ }^{26}$.

The prevalence of uric acid $\left(\mathrm{C}_{5} \mathrm{H}_{4} \mathrm{~N}_{4} \mathrm{O}_{3}\right)$ stones is $\sim 10-15 \%$ worldwide, and varies in populations according to sex and age ${ }^{27}$ (TABLE 1). The risk factors for uric acid stone formation include conditions associated with elevated concentrations of uric acid in the urine (hyperuricosuria), low urine volume, and low urine $\mathrm{pH}$ (which is the most common and most important risk factor) ${ }^{28}$. Uric acid stones are most commonly found in the pure form (anhydrous or dihydrate), whereas only a small fraction $(<1 \%)$ seem to be admixed with other stone components (ammonium acid urate or monosodium urate combined with calcium oxalate $)^{29}$.
Struvite (magnesium ammonium phosphate) stones - often referred to as infection stones - seem to be associated with UTIs ${ }^{11}$ (TABLE 1). Struvite stones account for $10-15 \%$ of urinary tract stones in the general population and occur more frequently in women than in men, probably owing to the higher occurrence of UTIs and the generally higher urine $\mathrm{pH}$ in women ${ }^{15}$.

Excess concentrations of cystine (a sulfur containing amino acid; $\mathrm{C}_{6} \mathrm{H}_{12} \mathrm{~N}_{2} \mathrm{O}_{4} \mathrm{~S}_{2}$ ) in urine can lead to cystine precipitation and the formation of cystine stones (TABLE 1). Despite the low prevalence in the population, cystine stone formers ( $~ 1 \%$ of adults and $6-8 \%$ of paediatric patients) are a challenging group for medical treatment owing to the intrinsic characteristics of these stones (such as hardness) and the poor effectiveness of available nonsurgical treatments ${ }^{30}$.

Only $1-2 \%$ of all urinary stones have been reported to be induced by medications ${ }^{31}$ (TABLE 1). However, evidence has emerged that a number of drugs seem to have a tendency to cause crystalluria. Stone formation induced by drugs can occur in two ways: drugs (such as loop diuretics, uricosurics, carbonic anhydrase inhibitors, antiobesity drugs, and laxatives $)^{31}$ can induce metabolic abnormalities that can lead to the formation of stones; and supersaturation of urine with the drug (which can be due to drug insolubility) can induce the precipitation of crystals comprised of the drug itself, which can then lead to stone formation (for example, stones made of drugs such as acyclovir, atazanavir, indinavir, methotrexate, triamterene, and ciprofloxacin) ${ }^{31,32}$. Risk factors for drug-induced stone formation include high daily drug doses, low drug solubility, long-term treatment, high levels of drug excretion via the urine, and low urine volume ${ }^{31}$.

\section{Infection stones}

Infection stone formation is one of the most problematic stone diseases owing to the potential for the rapid growth of struvite stones in the human body, the high recurrence rates, and the tendency of infection stones to aggregate into larger stones (staghorn calculi) that can fully occupy the renal pelvis and branch into the renal calyces $^{11}$. Complications associated with the development of kidney stones include pyonephrosis, perinephric abscess formation, and xanthogranulomatous pyelonephritis, which can lead to renal failure, potential loss of the kidney, and even death in some patients ${ }^{33,34}$. Early reports suggested that untreated staghorn stone formers had a $50 \%$ chance of losing one kidney ${ }^{35}$; however, subsequent studies have shown that $\sim 14 \%$ of patients undergoing conservative management of staghorn calculi had progressive renal failure, and $9 \%$ of the patients required dialysis owing to the deterioration of renal function ${ }^{36}$.

\section{Riskfactors}

Risk factors associated with infection stone formation include: female gender (usually a 2:1 ratio compared to males), which is associated with a high frequency of $\mathrm{UTIs}^{15}$; age, given that infection stones seem to be most frequent in elderly patients ${ }^{37}$; anatomical alterations of the urinary tract such as ureteropelvic junction stenosis $^{38}$; urinary diversion ${ }^{39}$ and urinary stasis ${ }^{40}$ as a result of 
Table 1 | Classification of urinary stones

\begin{tabular}{|c|c|c|c|c|c|c|}
\hline Urinary stone & Composition & $\begin{array}{l}\text { Description and } \\
\text { formation }\end{array}$ & Frequency & Risk factors & $\begin{array}{l}\text { Treatment and } \\
\text { prevention }\end{array}$ & Refs \\
\hline $\begin{array}{l}\text { Calcium } \\
\text { stones }\end{array}$ & $\begin{array}{l}\text { - Calcium oxalate } \\
\text { monohydrate: } \\
\mathrm{CaC}_{2} \mathrm{O}_{4} \cdot \mathrm{H}_{2} \mathrm{O} \\
\text { - Calcium oxalate } \\
\text { dihydrate: } \\
\mathrm{CaC}_{2} \mathrm{O}_{4} \cdot 2 \mathrm{H}_{2} \mathrm{O} \\
\text { - } \mathrm{Calcium}_{2} \text { oxalate } \\
\text { trihydrate: } \\
\mathrm{CaC}_{2} \mathrm{O}_{4} \cdot 3 \mathrm{H}_{2} \mathrm{O} \\
\text { - } \mathrm{Hydroxyapatite} \\
\text { (calcium phosphate): } \\
\mathrm{Ca}_{10}(\mathrm{OH})_{2}\left(\mathrm{PO}_{4}\right)_{6} \\
\text { - } \mathrm{Carbapatite} \\
\text { (calcium phosphate): } \\
\mathrm{Ca} \mathrm{a}_{10}\left(\mathrm{PO}_{4}\right)_{6} \mathrm{CO}_{3} \\
\text { - Brushite }(\text { calcium } \\
\text { phosphate): } \\
\mathrm{CaHPO} \cdot 2 \mathrm{H}_{2} \mathrm{O} \\
\text { - Whitlockite }(\text { calcium } \\
\text { phosphate): } \mathrm{Ca}_{3}\left(\mathrm{PO}_{4}\right)_{2}\end{array}$ & $\begin{array}{l}\text { - Most common urinary } \\
\text { stones } \\
\text { - 80\% of calcium stones } \\
\text { are calcium oxalate } \\
\text { - Pure calcium phosphate } \\
\text { stones are less frequent } \\
\text { than calcium oxalate } \\
\text { stones } \\
\text { - Most calcium-based } \\
\text { stones are comprised of } \\
\text { calcium oxalate admixed } \\
\text { with calcium phosphate } \\
\text { - Calcium oxalate stones } \\
\text { usually form over an } \\
\text { initial calcium phosphate } \\
\text { layer }\end{array}$ & $70-80 \%$ & $\begin{array}{l}\text { - Hypercalciuria } \\
\text { (calcium oxalate } \\
\text { dihydrate) } \\
\text { - Hypocitraturia } \\
\text { - Hyperoxaluria } \\
\text { (calcium oxalate } \\
\text { monohydrate) } \\
\text { - Hypercalciuria and } \\
\text { alkaline urinary pH } \\
>6.0 \text { (phosphate } \\
\text { stones) }\end{array}$ & $\begin{array}{l}\text { - Calcium oxalate } \\
\text { stones: decreasing } \\
\text { urinary oxalate } \\
\text { excretion (for } \\
\text { example, by } \\
\text { restricting intake } \\
\text { of animal protein } \\
\text { and salt combined } \\
\text { with normal calcium } \\
\text { intake), increasing } \\
\text { urine volume, and } \\
\text { surgical treatment } \\
\text { - Calcium phosphate } \\
\text { stones: decreasing } \\
\text { urinary calcium } \\
\text { excretion (for } \\
\text { example, using } \\
\text { thiazide diuretics) } \\
\text { and increasing urine } \\
\text { volume }\end{array}$ & $17,19,21,23-25$ \\
\hline $\begin{array}{l}\text { Uric acid } \\
\text { stones }\end{array}$ & $\mathrm{C}_{5} \mathrm{H}_{4} \mathrm{~N}_{4} \mathrm{O}_{3}$ & $\begin{array}{l}\text { Uric acid forms as the } \\
\text { end product of purine } \\
\text { degradation } \\
\text { - Low urinary pH promotes } \\
\text { the precipitation of uric } \\
\text { acid, leading to crystal } \\
\text { precipitation }\end{array}$ & $10-15 \%$ & $\begin{array}{l}\text { Low urine } \mathrm{pH} \\
\text { - Hyperuricosuria }\end{array}$ & $\begin{array}{l}\text { - Urinary alkalization } \\
\text { - Increasing urine } \\
\text { volume } \\
\text { - Low-purine diet } \\
\text { - Pharmacological } \\
\text { agents that inhibit } \\
\text { the degradation of } \\
\text { purines to uric acid }\end{array}$ & $7,28,29$ \\
\hline Struvite stones & $\mathrm{MgNH}_{4} \mathrm{PO}_{4} \cdot 6 \mathrm{H}_{2} \mathrm{O}$ & $\begin{array}{l}\text { - Also known as infection } \\
\text { stones in combination } \\
\text { with carbapatite } \\
\text { - Ammonia is generated by } \\
\text { the enzymatic hydrolysis } \\
\text { of urea, elevating the } \\
\text { pH of urine and leading } \\
\text { to the supersaturation } \\
\text { and crystallization of } \\
\mathrm{MgNH}_{4} \mathrm{PO}_{4}\end{array}$ & $10-15 \%$ & $\begin{array}{l}\text { Urinary tract infections } \\
\text { (urea-hydrolysing } \\
\text { bacteria) }\end{array}$ & $\begin{array}{l}\text { - Urinary acidification } \\
\text { - Urease inhibitors } \\
\text { - Dissolution therapy } \\
\text { - Manipulation of } \\
\text { urine chemistry } \\
\text { - ESWL } \\
\text { - Antimicrobials }\end{array}$ & $11,13,44,138,171$ \\
\hline $\begin{array}{l}\text { Drug-induced } \\
\text { stones }\end{array}$ & $\begin{array}{l}\text { Comprised of drugs } \\
\text { such as acyclovir, } \\
\text { atazanavir, indinavir, } \\
\text { methotrexate, } \\
\text { triamterene, or } \\
\text { ciprofloxacin }\end{array}$ & $\begin{array}{l}\text { The use of drugs can } \\
\text { induce the formation } \\
\text { of stones made of the } \\
\text { drug itself (for example, } \\
\text { acyclovir, atazanavir, } \\
\text { indinavir, methotrexate, } \\
\text { triamterene, or } \\
\text { ciprofloxacin), or can } \\
\text { induce the formation } \\
\text { of metabolic stones (for } \\
\text { example, loop diuretics, } \\
\text { uricosurics, carbonic } \\
\text { anhydrase inhibitors, } \\
\text { antiobesity drugs, and } \\
\text { laxatives) }\end{array}$ & $1-2 \%$ & $\begin{array}{l}\text { - Physiological changes } \\
\text { (for example, low } \\
\text { urine volume) } \\
\text { - Drugs prone to cause } \\
\text { crystalluria } \\
\text { - High drug doses } \\
\text { - Long-term drug } \\
\text { treatments } \\
\text { - High urinary drug } \\
\text { excretion and poor } \\
\text { drug solubility }\end{array}$ & $\begin{array}{l}\text { - Cessation of drug } \\
\text { use } \\
\text { - Urinary alkalinization } \\
\text { or acidification, } \\
\text { depending on the } \\
\text { drug } \\
\text { - Increasing urine } \\
\text { volume }\end{array}$ & 31,32 \\
\hline
\end{tabular}

ESWL, extracorporeal shock wave lithotripsy.

obstruction; neurogenic bladder dysfunction as a result of neurological disorders ${ }^{41}$ such as spinal cord injury, spina bifida, and multiple sclerosis; indwelling catheters ${ }^{42}$; and diabetes mellitus ${ }^{43}$.
Owing to the low incidence of metabolic abnormalities in struvite stone formers and the apparent strong association between struvite stone formation and UTIs, the 2005 American Urological Association (AUA) 
guidelines on management of staghorn calculi recommended against the metabolic evaluation of pure struvite stone formers ${ }^{44}$. However, studies published after 2005 suggest that metabolic abnormalities occur more frequently in struvite stone formers, including patients with pure struvite stones, than previously reported ${ }^{45,46}$. For instance, a 2017 study by Iqbal et $a .^{45}$ found metabolic abnormalities in $57 \%$ of pure struvite stone formers (from a total of 75 patients), the most common of which were hypercalciuria, hyperoxaluria, hyperuricosuria, and hypocitraturia. These findings suggest that future work should evaluate the effect of therapies for metabolic diseases on the incidence of struvite stone formation ${ }^{45}$.

\section{Mineral composition and stone matrix}

Struvite stones (also known as triple phosphate stones) are composed of magnesium, ammonium, and phosphate with the chemical formula $\mathrm{MgNH}_{4} \mathrm{PO}_{4} \cdot 6 \mathrm{H}_{2} \mathrm{O}$ $\left(\mathrm{REF}^{11}{ }^{11}\right.$ ). Struvite is frequently combined with calcium phosphate (mostly carbapatite) and calcium oxalate, resulting in the formation of so-called infection stones. A retrospective study with 121 recovered struvite stones showed that only $\sim 13 \%$ were homogenously composed of struvite, whereas $\sim 87 \%$ contained struvite admixed with other mineral components, the order of abundance of which was calcium phosphate, calcium oxalate, calcium carbonate, and uric acid ${ }^{47}$. On average, $~ 35 \%$ of recovered struvite stones are composed of struvite with or without carbapatite, and $\sim 65 \%$ comprise struvite stones admixed with calcium oxalate ${ }^{45,46,48}$.

The stone matrix - an organic matrix that holds together the mineral fraction of the stones - has been identified in most types of urinary stone. Approximately $1-3 \%$ of the dry weight of a stone is attributable to the stone matrix, which is composed of organic macromolecules including proteins, carbohydrates, glycosaminoglycans, and lipids ${ }^{49}$. The composition of the stone matrix is quite variable (TABLE 2) and depends on the nature of the mineral, but patient-specific differences in stone matrix composition have been observed among similar stone types ${ }^{50}$. Compared with other stone types, struvite stones have the lowest percentage of organics $(<1 \%)^{49,51}$. Khan et al. ${ }^{52}$ reported higher lipid contents in calcium oxalate and calcium phosphate stones than uric acid and struvite stones. Struvite and uric acid stones had similar lipid content ( $\sim 26 \%$ of the organic matrix) and protein:lipid ratios (3:1), but the lipid matrix of struvite stones contained higher amounts of triglycerides, cholesterol, and sulfatides ${ }^{52}$. Slightly different results were reported by Boonla and colleagues ${ }^{50}$, who found higher lipid content in struvite and calcium oxalate stone matrices than in uric acid stones. The content of proteins in the organic matrix of struvite stones was reported to be $\sim 74 \%{ }^{52}$. Specific glycosaminoglycans such as chondroitin sulfate, low-sulfated chondroitin, and hyaluronic acid, have also been observed in the stone matrix of struvite ${ }^{53,54}$.

\section{Stone characteristics}

Infection stones are conglomerates of biominerals (or biogenic minerals) that can be defined as composite materials containing an organic matrix and nanoscale or microscale amorphous or crystalline minerals ${ }^{55}$. The lithogenesis of infection stones and the resultant characteristics of a given stone seem to be heavily dependent on the urinary composition and on the interaction of bacteria with the various urinary components. Unsurprisingly, the formation and physical characteristics of infection stones differ substantially from those formed in the absence of bacteria ${ }^{55}$. Differences in struvite crystal formation under varying conditions have previously been observed ${ }^{56-61}$; crystallization in the presence of bacteria seems to lead to the formation of crystals with defined faces and specific surface structures compared to those formed in the absence of bacteria ${ }^{56,58,59,62-64}$. Overall stone morphology is expected to be affected by the physical presence of bacteria within the stone matrix, but morphology also seems to be heavily influenced by the degree of $\mathrm{pH}$ change induced by bacteria. Sadowski et al. ${ }^{60}$ observed the formation of single coffin-like struvite crystal morphologies at low $\mathrm{pH}$ accompanied by a slow increase in the $\mathrm{pH}$ of artificial urine in the absence of bacteria, whereas rapid changes in $\mathrm{pH}$ induced by urease-positive bacteria resulted in the formation of dendrite-like (X-shaped) struvite crystals $^{60}$. The formation of large struvite crystals seems to be associated with dendrite-like crystal morphology ${ }^{60,61}$.

Aside from their physical appearance, the presence of bacteria during struvite stone formation is associated with increased porosity ${ }^{59}$. The porous nature of struvite stones substantially influences their mechanical properties, which possibly explains why they are relatively soft and fragile compared with other kidney stones ${ }^{65,66}$ (TABLE 2). The presence of organic components in the stone matrix has been suggested to harden urinary stones and decrease their solubility ${ }^{67}$, which could explain the correlation between the low percentage of

Table 2 | Organic composition and mechanical characteristics of urinary stones

\begin{tabular}{llllll|} 
Crystal & $\begin{array}{l}\text { Hardness } \\
\text { index }^{\mathbf{a}}\end{array}$ & $\begin{array}{l}\text { Porosity } \\
\mathbf{( \% )}^{\mathbf{b}}\end{array}$ & $\begin{array}{l}\text { Organic content } \\
\text { in stone matrix } \\
\mathbf{( \% )}^{\mathbf{c}}\end{array}$ & $\begin{array}{l}\text { Protein content } \\
\text { in stone matrix } \\
\mathbf{( \% )}^{\mathbf{d}}\end{array}$ & $\begin{array}{l}\text { Lipid content } \\
\text { in stone matrix } \\
(\%)^{\mathbf{d}}\end{array}$ \\
\hline Cystine & 2.4 & 1.5 & 9 & ND & ND \\
\hline Calcium phosphate & $1.3-2.2$ & 9 & $3.2-6$ & 33 & 67 \\
\hline Calcium oxalate & 1.3 & 8 & $2-3.2$ & 20 & 80 \\
\hline Uric acid & 1 & 9 & $0.3-0.9$ & 75 & 25 \\
\hline Struvite & 1 & 14 & $0.3-1.1$ & 74 & 26
\end{tabular}

ND, not determined. ${ }^{a}$ Hardness index data were obtained from Ringdén et al. ${ }^{65}$; the higher the index number, the harder the material. ' Porosity data were obtained from Cohen et al. ${ }^{201}$. 'Organic content in stone matrix data were obtained from Boyce et al. ${ }^{49}$ and Khan et al. ${ }^{52}$. PProtein and lipid content in stone matrix data were obtained from Khan et al. ${ }^{52}$. 


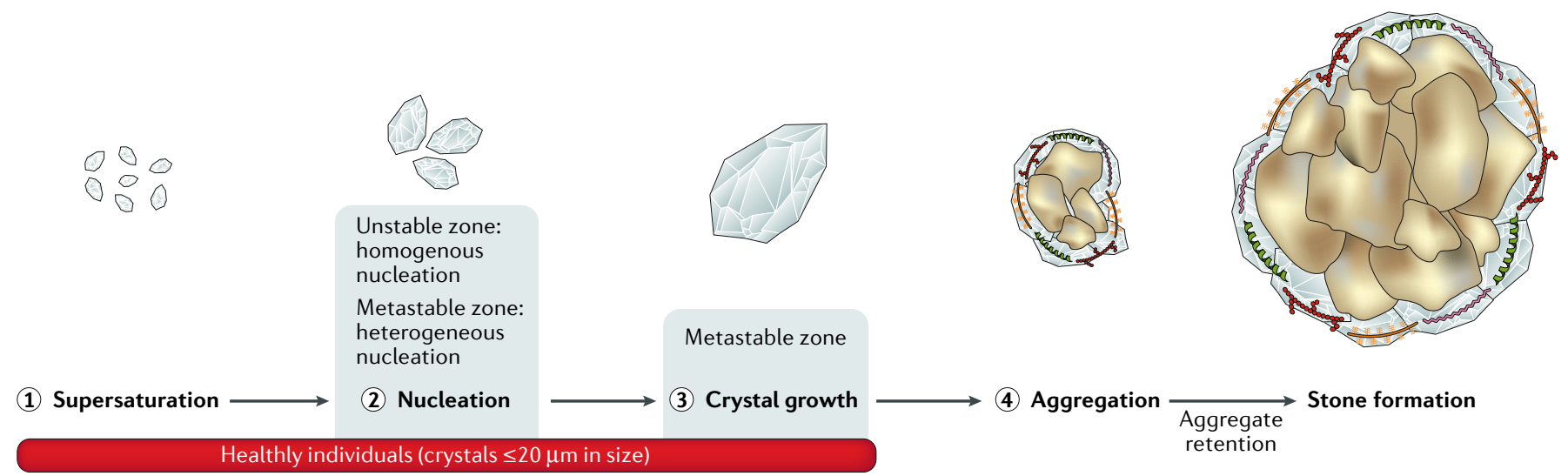

Fig. 1 | Physicochemical process of stone formation. Stone formation is the result of a physicochemical process involving roughly four steps that leads to the deposition of minerals in the urinary tract ${ }^{81,200}$. Supersaturation refers to the presence of solutes in solution at higher concentrations than that of their own solubility, and is a prerequisite for stone formation (step 1). During the nucleation step, solutes combine into clusters resulting in the formation of microscopic particles. Nucleation can occur either homogeneously (at extremely high degrees of supersaturation, at which nucleation occurs spontaneously; 'unstable zone') or heterogeneously (occurs in the 'metastable zone', a region with a lower degree of supersaturation than is required for spontaneous nucleation; the presence of a surface is necessary for nucleation) ${ }^{75}$ (step 2). After the crystal nucleus has reached a critical size, it grows as a result of continuous exposure to saturated urine ('metastable zone'), which enables the movement of ions from solution onto the crystal (step 3). During aggregation, preformed crystals conglomerate to form larger particles that are usually embedded in a matrix of organic macromolecules (for example, proteins, carbohydrates, glycosaminoglycans, and lipids) termed the stone matrix. Crystal nucleation and growth also commonly occurs in individuals who do not form stones, but the size of the crystals $(\leq 20 \mu \mathrm{m})$ usually enables them to pass through the urinary $\operatorname{tract}^{74}$. Particulates $>20 \mu \mathrm{m}$ often cannot be expelled from the urinary tract and, therefore, cause obstruction, pain, or recurrent infections (step 4).

organics found in the struvite stone matrix and its softness relative to other stones (TABLE 2). These mechanical properties enable struvite stones to be broken down relatively easily during treatment, but the resulting multitude of stone fragments of various sizes can lead to the release of infectious bacteria from the stones back into the urinary tract, raising the risk of possible reinfection and, therefore, stone recurrence ${ }^{68}$.

\section{Infection stone formation}

The formation of urinary stones is a very complex process that involves various physicochemical, biochemical, and physiological factors. Different from other types of urinary stones, the physicochemical processes that lead to infection stone formation are largely driven by the presence of ureolytic microorganisms in the urinary tract system.

Randall's plaque has been suggested to have a key role in the lithogenesis of calcium oxalate stones ${ }^{69}$, but seems to have a limited role in struvite stone formation ${ }^{70}$. Indeed, Jaeger et al. ${ }^{70}$ reported substantially lower levels of Randall's plaque formation in struvite stone formers than in calcium oxalate stone formers. Owing to the lack of or low abundance of Randall's plaque, the authors suggested that struvite formation is probably independent of the presence of Randall's plaque.

\section{Physicochemical processes}

Randall's plaque Plaques of calcifications deposited in the interstitial tissue of the renal papilla. stone types is still not clearly understood. Similar to other stone types, infection stone formation is the result of a physicochemical process involving roughly four steps - supersaturation, nucleation, crystal growth, and aggregation - that lead to the deposition of minerals along the urinary tract (FIG. 1). Urine chemistry has a key role in stone formation and is determined by the saturation conditions, $\mathrm{pH}$, and the presence of impurities in the urine (BOX 1).

Supersaturation. Supersaturation represents the chemical potential for the formation of a crystal nucleus and, therefore, crystal formation. The degree of saturation and potential for spontaneous precipitation of struvite from aqueous solutions (for example, urine) depends on the concentration of solutes, $\mathrm{pH}$, and ionic strength ${ }^{73}$. Although supersaturation in urine is a prerequisite for stone formation, this phenomenon is also observed in non-stone-formers ${ }^{74}$. Supersaturation is only the first step in the complex process of stone formation, in which crystals need not only to be formed, but also retained, in the urinary tract. Determination of supersaturation in urine can be used as an indicator of the overall risk of stone formation, but further investigations should be performed for the appropriate medical management of patients.

Nucleation. The process by which solutes combine into clusters leading to the formation of microscopic particles is known as nucleation. This process is the first step in crystal formation and can occur either homogeneously or heterogeneously. Homogeneous nucleation generally occurs in solution at high supersaturation, during which nucleation can occur spontaneously 


\section{Box 1 | Factors influencing urinary crystal formation}

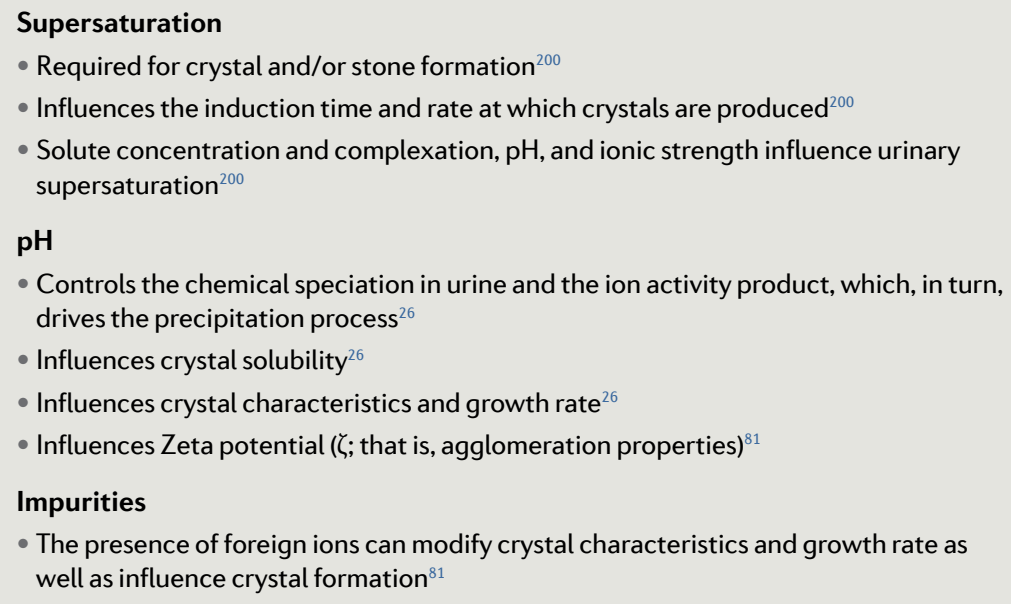

\section{Zeta potential}

Measure of the magnitude of the electrostatic or charge repulsion or attraction between particles in colloidal systems. ('unstable zone'), whereas heterogeneous nucleation occurs generally in the presence of a solid phase (for example, proteins, cellular material, and crystals) and at a lower degree of supersaturation ${ }^{75}$ (FIG. 1). Given the complex composition of urine, crystallization in urine has been suggested to mainly occur via heterogeneous nucleation ${ }^{76}$. The presence of modulators in urine can influence the nucleation process of struvite (TABLE 3). For example, urinary metabolites such as citrate ${ }^{77}$ and pyrophosphate ${ }^{78}$, can inhibit struvite nucleation, whereas glycosaminoglycans such as chondroitin sulfate can promote struvite nucleation ${ }^{79,80}$.

Crystal growth. Crystal growth occurs when the crystal nucleus reaches a critical size and the continuous exposure to saturated urine ('metastable zone') enables the movement of ions from the solution onto the crystal ${ }^{81}$. The rate of crystal growth is determined by the degree of local supersaturation and can be influenced by the presence of modulators (promoters or inhibitors) ${ }^{82,83}$; important modulators that affect crystal growth of struvite include citrate, pyrophosphate, and phosphocitrate (TABLE 3). Crystal growth based on the movement of ions from solution commonly results in small crystals ${ }^{84}$. Stone formation is more likely to occur as a result of the aggregation of pre-existing crystals or secondary nucleation (nucleation induced owing to the presence of pre-existing crystals) than metastable zone crystal growth alone. The nucleation and growth of microscopic crystals is also common in the urine of individuals who do not form stones, but the crystals formed are small enough $(\leq 20 \mu \mathrm{m})$ to pass through the urinary tract without interacting with the epithelial cells ${ }^{74}$.

Aggregation. Following crystal growth, preformed crystals in solution can aggregate to form larger particles that are usually embedded in a stone matrix ${ }^{49}$. Crystal aggregation is suggested to have a key role in stone formation given that this process, unlike crystal growth, can occur in a matter of seconds to form aggregates that are large enough $(>20 \mu \mathrm{m})$ to be retained in the urinary tract ${ }^{84}$. Compared with healthy individuals, the urine of stone formers is characterized by the presence of conglomerations of crystals with a broader particle size distribution ${ }^{85}$. Aggregation is governed by the surface charge of the particles and is usually measured with the zeta potential $(\zeta)$, which depends on the nature of the particles and the surrounding conditions (such as the $\mathrm{pH})$. A high $\zeta$ value $(\zeta>+30 \mathrm{mV}$ or $\zeta<-30 \mathrm{mV})$ reduces the probability of crystal aggregation ${ }^{85}$. Prywer et al. ${ }^{86}$ studied the tendency for the different components of struvite stones (that is, struvite, carbapatite, and Proteus mirabilis cells) to aggregate by determining their $\zeta$ value and reported that the formation of infection stones is, to some extent, driven by carbapatite precipitation and aggregation; carbapatite had a lower $\zeta$ value than struvite and $P$. mirabilis cells, in a $\mathrm{pH}$ range between 7.0 and 9.5. Future preventive strategies for infection stones could focus on finding modulators of the crystal $\zeta$ that inhibit the aggregation of carbapatite crystals.

\section{Role of the stone matrix}

The stone matrix has been observed in most urinary stones and is composed of organic macromolecules such as proteins, carbohydrates, glycosaminoglycans, and lipids ${ }^{49}$. Although some efforts have been made to characterize the composition of organic molecules associated with urinary stones, a complete understanding of their exact origin and function is still lacking given the limited information as to how different components are incorporated into the stones. The role of the stone matrix in the lithogenesis and pathogenesis of urinary stones is debatable, but two main hypotheses exist regarding the function of these complex organic molecules ${ }^{49}$, which specifically state that the matrix actively participates in the assemblage of stones, functioning as a template and controlling crystallization and that the matrix does not have a key role in the genesis of the stones, but rather formation of the matrix is a result of the constant exposure of the crystals to urinary macromolecules, which leads to their subsequent incorporation. The composition of the stone matrix is quite variable (TABLE 2), even among similar stone types ${ }^{87}$. The presence of organic components in the stone matrix has been suggested to harden urinary stones and decrease their solubility ${ }^{87}$. Thus, the stone matrix composition has a direct influence on the potential medical treatment options for urinary stones.

Lipids. Regardless of the inorganic composition of urinary stones, lipids have been detected in almost all of the stone matrices examined to date ${ }^{50,52,88}$. Khan et al. ${ }^{88}$ reported the presence of lipids in urinary stones, as evidenced by the content of sudanophilic and osmiophilic substances in stone sections, which had previously been attributed to the presence of glycoproteins ${ }^{89}$. The stone matrix can contain different lipid classes, including phospholipids, cholesterol, free fatty acids, and glycolipids ${ }^{50,52,88}$. Lipids have been suggested to actively participate in lithogenesis by promoting crystal nucleation and modulating crystal growth ${ }^{52}$. Complexation of phospholipids with calcium and inorganic phosphate has been suggested as the first step in calcification, leading to the nucleation of calcium phosphate ${ }^{90,91}$. Similarly, the lipid matrix was shown to promote the nucleation of calcium oxalate crystals ${ }^{92}$. 
Table 3 | Effect of modulators on struvite crystallization

\begin{tabular}{|c|c|c|c|c|c|}
\hline Modulator & $\begin{array}{l}\text { Effect on } \\
\text { nucleation }\end{array}$ & $\begin{array}{l}\text { Effect on } \\
\text { growth }\end{array}$ & $\begin{array}{l}\text { Effect on } \\
\text { aggregation }\end{array}$ & $\begin{array}{l}\text { Effect on cell } \\
\text { adhesion }\end{array}$ & Refs \\
\hline \multicolumn{6}{|l|}{ Urinary metabolites } \\
\hline Citrate & Inhibition & Inhibition & - & - & 77 \\
\hline Phosphocitrate & - & Inhibition & - & - & 78 \\
\hline Pyrophosphate & Inhibition & Inhibition & - & - & 202 \\
\hline \multicolumn{6}{|l|}{ Glycosaminoglycans } \\
\hline Chondroitin sulfate & $\begin{array}{l}\text { No effect; } \\
\text { promotion }\end{array}$ & No effect & No effect & Enhancement & 100 \\
\hline Heparin sulfate & - & No effect & - & - & 100 \\
\hline \multicolumn{6}{|l|}{ Plant extracts } \\
\hline Commiphora wightii & - & Inhibition & - & - & 203,204 \\
\hline Boerhaavia diffusa Linn & - & Inhibition & - & - & 204 \\
\hline Rotula aquatic Lour & - & Inhibition & - & - & 204 \\
\hline $\begin{array}{l}\text { Orthosiphon aristatus (BL.) } \\
\text { MIQ }\end{array}$ & - & Inhibition & - & - & 205 \\
\hline
\end{tabular}

Data from REFS 82,206 .

Proteins. Proteins have been identified as common components of the stone matrix and have been suggested to have an important, although poorly understood, role in stone formation. Proteins might actively participate in stone formation or simply accumulate as stones grow. The protein content of the stone matrix might originate from urinary proteins, circulating cells and plasma proteins derived from local injuries caused by the movement of stones ${ }^{93}$, proteins associated with inflammation and fibrosis ${ }^{93,94}$, and perhaps proteins produced by microorganisms associated with UTIs.

The characterization of proteins in urinary stones has been limited owing to the poor solubility of the protein-crystal complex. However, proteomic analyses of both urinary proteins and human stone matrices have been published ${ }^{87,94-98}$. The protein composition of stones and the stone matrix seems to be quite variable, even among similar stone types, suggesting patient specificity in stone composition ${ }^{87}$. A range of stone matrix proteins have been identified to date, including those associated with immune responses, inflammation, tissue injury, and tissue repair. The most common and abundant proteins detected in the matrix of all studied stone types (calcium oxalate, calcium phosphate, uric acid, and struvite stones) include serum albumin, apolipoproteins, calgranulins (also known as $\$ 100$ proteins), and haemoglobin subunits ${ }^{87,93-98}$. Proteins involved in inflammatory and fibrotic processes - which are usually associated with crystal deposition in the kidneys - are prominent in the stone matrix of all stone types studied $^{87,93-98}$. However, the role of inflammatory and fibrotic proteins in the urinary tract during stone formation remains unclear. If such proteins are produced during an inflammatory response caused by the presence of crystals, they could have a direct role in stone formation, or could simply accumulate nonspecifically as the crystal and/or stone grows. Boonla et al.$^{93}$ suggested the use of calcium-binding protein S100-A8 (also known as calgranulin-A) as a biomarker for kidney stones. This inflammation-associated protein was found to be abundant in the stone matrix of calcium oxalate, uric acid, and struvite stones, as well as in nephrolithiatic urine, but was undetectable in urine from healthy individuals ${ }^{93}$.

Glycosaminoglycans. Glycosaminoglycans are linear polyanionic polysaccharides composed of repeating disaccharide units (formed of an amino sugar and uronic acid or galactose). Glycosaminoglycans, including chondroitin sulfate, keratin, heparan sulfate, dermatan sulfate, and hyaluronic acid, are commonly found in the urinary tract and urine of healthy individuals ${ }^{99}$. Importantly, glycosaminoglycans have been isolated from the matrix of urinary stones, irrespective of their inorganic composition ${ }^{53,54}$, and account for up to $20 \%$ of the total mass organic matrix ${ }^{53,54}$. Specific glycosaminoglycans seem to be associated with certain stone (mineral) types. Chondroitin sulfate, low-sulfated chondroitin, and hyaluronic acid, in particular, have been observed in the stone matrix of struvite stones ${ }^{53,54}$. The presence of glycosaminoglycans in all types of stones (metabolic and infection stones) suggests that the source of glycosaminoglycans in the stone matrix could be either urine or the glycosaminoglycan layer of the urothelium. However, in the case of infection stones, the possibility that stone-matrix-associated bacteria produce glycosaminoglycans should not be ruled out.

The role of glycosaminoglycans in lithogenesis is unclear and controversial given that these urinary macromolecules have been reported to either inhibit or promote mineralization of struvite (9,80,100,101 $^{\text {(TABLE 3). }}$ The struvite matrix is characterized by a high fraction of chondroitin sulfate - the predominant glycosaminoglycan component in normal human urine ( $65 \%$ of total glycosaminoglycans $)^{102}$ - whereas heparan sulfate seems to be absent ${ }^{53}$. In contrast to struvite stones, the stone matrix of calcium oxalate stones seems to have a very low content of chondroitin sulfate ${ }^{54,103}$. The difference in the type of glycosaminoglycans present in struvite 
and calcium oxalate stones suggests that the inclusion of glycosaminoglycans into struvite could come from the glycosaminoglycans present in urine $e^{53}$. Indeed, stone formers have lower levels of urinary-excreted glycosaminoglycans compared with individuals who do not form stones, independent of metabolic disorders ${ }^{104}$.

\section{Biologically induced stone formation}

Infection stones seem to follow the well-described concept of biologically induced mineralization (BIM), which refers to the unintentional and uncontrolled precipitation of crystals induced by microbial metabolic processes and the consequential chemical reactions involving metabolic byproducts ${ }^{105}$. The crystals formed during BIM generally exhibit nonspecific morphologies unlike those formed via biologically controlled mineralization, a biomineralization process in which the microorganisms can control, to a great extent, the nucleation and growth of the crystals ${ }^{106}$. The formation of struvite seems to be the result of BIM; furthermore, some calcium-based stones have tested positive for microbial stone cultures (TABLE 4), which might indicate the potential role of BIM in the formation of calcium-based stones.

Microbial evaluation of urinary stones has revealed the presence of different microbial strains and species (TABLE 4), which might be associated with the lithogenic process. Assessment of the microorganisms associated with urinary calculi is most commonly performed using microbial cultures obtained from crushed stone samples. The microbial communities reported for urinary stones most commonly include bacteria such as Citrobacter spp., Escherichia coli, Enterococcus faecalis, Enterococcus faecium, Pseudomonas aeruginosa, P. mirabilis, Staphylococcus aureus, Staphylococcus epidermidis,

Table 4 | Microbial communities in urinary stones

\begin{tabular}{|c|c|c|c|c|}
\hline Type of stone & Patients (n) & Infected stones (\%) & Microbial composition ${ }^{a}$ & Refs \\
\hline Calcium oxalate (mixed) & 5 & $100 \%$ & $\begin{array}{l}\text { - Pseudomonas spp. }(100 \%)^{c} \\
\text { - Enterobacteria }(80 \%)^{c} \\
\text { - Gardnerella spp. }(80 \%)^{c}\end{array}$ & 107 \\
\hline $\begin{array}{l}\text { Calcium phosphate; calcium } \\
\text { oxalate }\end{array}$ & - & $66 \%$ & $\begin{array}{l}\text { - Mixed culture (26\%) } \\
\text { - Escherichia coli }(20 \%) \\
\text { - Staphylococcus spp. (15\%) }\end{array}$ & $\begin{array}{r}108 \\
\text { (abstract) }\end{array}$ \\
\hline- & 200 & $51 \%$ & $\begin{array}{l}\text { - Mixed culture (62\%) } \\
\text { - Monoculture (38\%) } \\
\text { - Enterococcus faecalis; Enterococcus faecium; } \\
\text { Escherichia coli; Staphylococcus epidermidis; } \\
\text { Staphylococcus haemolyticus; Proteus mirabilis; } \\
\text { Pseudomonas aeruginosa; Klebsiella pneumonia }\end{array}$ & 109 \\
\hline Non-struvite & 132 & $24 \%$ & $\begin{array}{l}\text { - Escherichia coli }(31.3 \%)^{c} \\
\text { - Pseudomonas aeruginosa }(28.1 \%)^{c} \\
\text { - Klebsiella pneumoniae }(9.4 \%)^{c} \\
\text { - Proteus mirabilis }(9.4 \%)^{c} \\
\text { - Enterobacter spp. }(6.3 \%)^{c} \\
\text { - Candida albicans }(3.1 \%)^{c} \\
\text { - Citrobacter spp. }(3.1 \%)^{c} \\
\text { - Serratia marcescens }(3.1 \%)^{c} \\
\text { - Staphylococcus cohnii }(3.1 \%)^{c}\end{array}$ & 110 \\
\hline Calcium oxalate; struvite & 63 & $\begin{array}{l}-38 \% \\
\text { Struvite }(27 \%) \\
\text { Calcium oxalate (11\%) }\end{array}$ & $\begin{array}{l}\text { Escherichia coli (50\% struvite; } 53 \% \text { calcium } \\
\text { oxalate) } \\
\text { - Proteus mirabilis ( } 86 \% \text { struvite; } 7 \% \text { calcium } \\
\text { oxalate) }{ }^{c}\end{array}$ & 112 \\
\hline $\begin{array}{l}\text { Struvite; calcium oxalate; } \\
\text { brushite }\end{array}$ & 86 & $\begin{array}{l}76 \% \\
\text { Struvite (56\%) } \\
\text { Calcium-based stones ( } 5 \%) \\
15 \% \text { of the infected stones } \\
\text { were not analysed for mineral } \\
\text { composition }\end{array}$ & $\begin{array}{l}\text { Struvite: mixed culture }(40 \%)^{\mathrm{d}} \text {; monoculture } \\
(60 \%)^{\mathrm{d}} \text { (Proteus mirabilis, Klebsiella spp., } \\
\text { Staphylococcus spp., Pseudomomas spp., } \\
\text { Escherichia coli, Yeast) } \\
\text { - Calcium-based stones: monoculture }(100 \%)^{\mathrm{d}} \\
\text { (Escherichia coli, Proteus mirabilis, } \\
\text { Pseudomonas spp.) }\end{array}$ & 113 \\
\hline $\begin{array}{l}\text { Calcium oxalate; calcium } \\
\text { oxalate and calcium } \\
\text { phosphate; struvite; struvite } \\
\text { and calcium oxalate; calcium } \\
\text { phosphate }\end{array}$ & 100 & $\begin{array}{l}\text { - } 31 \% \\
\text { Calcium oxalate }(16 \% \text { b) } \\
\text { - Calcium oxalate and calcium } \\
\text { phosphate }\left(15 \%^{\mathrm{b}}\right) \\
\text { - Struvite }\left(84 \%^{\mathrm{b}}\right) \\
\text { - Struvite and calcium oxalate } \\
\left(61 \%^{\mathrm{b}}\right) \\
\text { - Calcium phosphate }\left(20 \%^{\mathrm{b}}\right)\end{array}$ & $\begin{array}{l}\text { - Calcium oxalate: Enterobacter spp. }(66 \%)^{c} \text {, } \\
\text { Staphylococcus spp. }(33 \%)^{c} \\
\text { - Calcium oxalate and calcium phosphate: } \\
\text { Escherichia coli }(50 \%)^{c}, \text { Pseudomonas spp. }(50 \%)^{c} \\
\text { - Struvite: Escherichia coli }(27 \%)^{c}, \text { Pseudomonas } \\
\text { spp. }(27 \%)^{c} \text {, Proteus spp. }(18 \%)^{c} \text {, Enterobacter } \\
\text { spp. }(9 \%)^{c}, \text { Citrobacter spp. }(9 \%)^{c} \text {, Staphylococcus } \\
\text { aureus }(9 \%)^{c} \\
\text { - Struvite and calcium oxalate: Escherichia coli } \\
(37 \%)^{c}, \text { Proteus spp. }(12 \%)^{c}, \text { Citrobacter spp. }(25 \%)^{c} \text {, } \\
\text { Klebsiella spp. }(12 \%)^{c}, \text { Enterococcus faecalis }(12 \%)^{c} \\
\text { Calcium phosphate: Candida albicans }(100 \%)^{c}\end{array}$ & 114 \\
\hline
\end{tabular}

${ }^{a}$ Microbial characterization for each study was performed by stone culture. ${ }^{b}$ Denotes the $\%$ of stones with positive stone culture from the total of the respective stone type. ${ }^{c}$ Denotes $\%$ of stones tested positive for that specific microorganism. ${ }^{\mathrm{d} D e n o t e s} \%$ of total abundance. 
Staphylococcus haemolyticus (and other Staphylococcus spp.), Actinobacter baumanii, Morganella morganii, and Klebsiella pneumoniae (TABLE 4). The fact that nonureolytic microorganisms have been found among the most common pathogens recovered from stone samples (for example, certain $E$. coli strains ${ }^{107-114}$ ) suggests that these microorganisms contribute to stone formation.

Of note, most microbial community analyses in urinary stones have focused on bacteria, and the isolation and identification of other microorganisms have not been reported extensively. The presence of other microorganisms in urinary stones, such as fungi (for example, Candida spp.), although uncommon, has been described ${ }^{110,114,115}$. Indeed, O'Kane et al. ${ }^{115}$ reported the case study of a woman with a small calculus within the renal pelvis that was completely encapsulated within a fungal bezoar (fungal ball) of Candida dubliniensis; although the mineralogy of the stone was not described in detail, the authors suggested a probable association with uric acid stones (based on imaging; radiolucent on plain X-ray). Biologically induced stone formation is traditionally attributed to bacteria, but the role of other microorganisms should not be disregarded and should be the subject of future studies.

Ureolytic biomineralization of struvite stones. The formation of infection stones is the result of a complex interaction between urease-producing microorganisms (ureolytic) and urine chemistry. Stone formation seems to occur when the urine $\mathrm{pH}$ is elevated (a $\mathrm{pH}$ of $>7.2$ is often described as a threshold value) and when urine is supersaturated with respect to magnesium, phosphate, and ammonium ions ${ }^{11}$. However, although calcium, magnesium, and phosphate ions are common in human urine, the concentration of ammonium ions is often not high enough to induce struvite precipitation ${ }^{16}$ (unpublished observations, E.J.E.-O., B.H.E., D.L., and R.G.). Importantly, the unique combination of high ammonium ion concentrations and elevated urine $\mathrm{pH}$ that are required to trigger struvite precipitation is almost exclusively associated with the infection of the urinary tract with urea-hydrolysing microorganisms, the most common of which are Proteus spp., Klebsiella spp., Pseudomonas spp., Staphylococcus spp., and some strains of E. coli ${ }^{13,116}$.

Urea-hydrolysing microorganisms produce urease, an enzyme that catalyses the hydrolysis of urea in urine to form ammonia and carbon dioxide. At neutral and alkaline $\mathrm{pH}$, ammonia functions as a Lewis base and forms ammonium and hydroxide ions, a process that results in the alkalinization of urine and an increase in the ammonium ion concentration, which can induce struvite precipitation (FIC. 2). Furthermore, given that quaternary amines are the only ions with a greater affinity for sulfated glycosaminoglycans than water, the presence of ammonium ions can damage the urothelial glycosaminoglycan layer, which combines with water to form a hydrophilic coating and functions as a protective layer that reduces the adhesion or attachment of crystals and bacteria to urothelial cells ${ }^{117}$. Thus, the binding of ammonium ions to sulfated glycosaminoglycans has been suggested to diminish their hydrophilicity, resulting in a potential increase in the amount of crystals, bacteria, and macromolecules that adhere to the urothelium ${ }^{117}$. According to the fixed particle model of stone formation ${ }^{9,72,118}$, which suggests that the attachment of crystals to the epithelial lining is necessary for stone formation, the adherence of crystals to the urothelium would permit sufficient time for these crystals to grow. Thus, the formation of larger aggregates would be highly likely under these conditions ${ }^{118}$. Bacterial adhesion also seems to be influenced by damage to the glycosaminoglycan layer by enabling bacterial colonization in the urothelium ${ }^{119}$, which might have a role in infection stone formation by providing the necessary conditions to promote biofilm formation (FIG. 2).

Urea hydrolysis also results in the production of carbonate and bicarbonate ions, which, in turn, can promote the precipitation of carbapatite (FIG. 2). Precipitation of carbapatite starts at a $\mathrm{pH}$ of $\sim 6.8$, after which carbapatite crystals seem to form large aggregates under high $\mathrm{pH}$ conditions $(\sim \mathrm{pH} 8.5)^{86}$. Given that carbapatite has a lower electronegativity than struvite, carbapatite precipitation and aggregation have been suggested as the first step in staghorn stone formation ${ }^{86}$.

Among urea-hydrolysing microbial species, $P$. mirabilis is frequently found as part of the microbial composition of infected stones (TABLE 4). P. mirabilis is also a common bacterial species associated with UTIs and catheter encrustation and blockage, and has been reported to be involved in $1-10 \%$ of all UTIs ${ }^{120}$ and in up to $44 \%$ of catheter-associated UTIs in the USA ${ }^{121}$. This species is typically found in urine cultures of patients with complicated UTIs, such as patients with spinal cord injury $^{122}$. P. mirabilis possesses unique characteristics that are of relevance in the pathophysiology of UTIs ${ }^{123}$. Specifically, P. mirabilis: has a coating layer of exopolysaccharides that functions as a protective capsule against the host defenses and seems to regulate attachment to either the epithelium or catheters ${ }^{124}$; expresses fimbriae, which might mediate bacterial attachment to the urothelium or catheters ${ }^{124}$; hydrolyses urea faster than many other bacterial species ${ }^{125}$; can migrate rapidly over solid surfaces using a mechanism called swarming motility ${ }^{126}$, which probably enables fast colonization of large parts of the urinary tract; and can develop biofilms, which increase resistance to antibacterial treatment ${ }^{127}$ and enable colonization in environments with high flow velocities $^{128}$.

Potential role of microorganisms in calcium-based stone formation. Lithogenesis of calcium-based stones is commonly attributed to metabolic disorders ${ }^{19-21}$. However, the role of microorganisms in the formation of calcium-based stones has not been fully investigated. Some urinary stones, including those comprised of calcium oxalate, calcium phosphate, or their combination with other stone types, test positive for stone cultures (TABLE 4), suggesting a possible association between bacteria and urinary stones. For instance, in a study of 100 patients with urolithiasis, positive stone cultures were observed for $16 \%$ of pure calcium oxalate stones, $15 \%$ of calcium oxalate-calcium phosphate stones, $85 \%$ of pure struvite stones, $61 \%$ of struvite-calcium oxalate stones, surfaces powered by rotating flagella.
Swarming motility

Rapid multicellular bacterial 
(1)

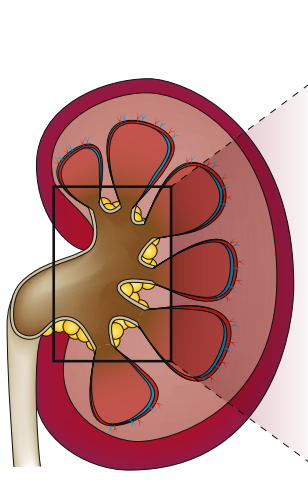

acterial attachment

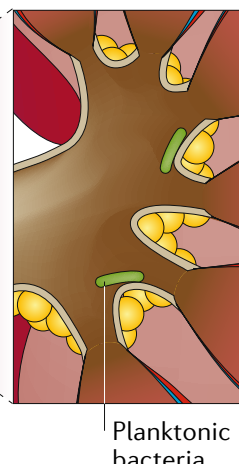

(2)

Bacterial growth and EPS production

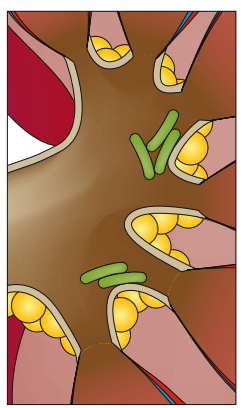

(3)

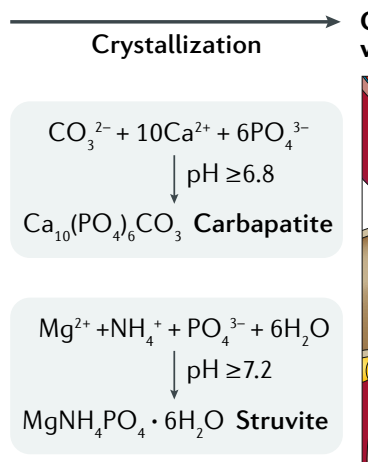

Crystal formation within EPS

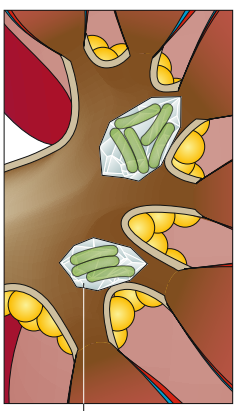

Crystal
(4) Microcolony formation around pre-existing crystals and formation (5) Infection stone

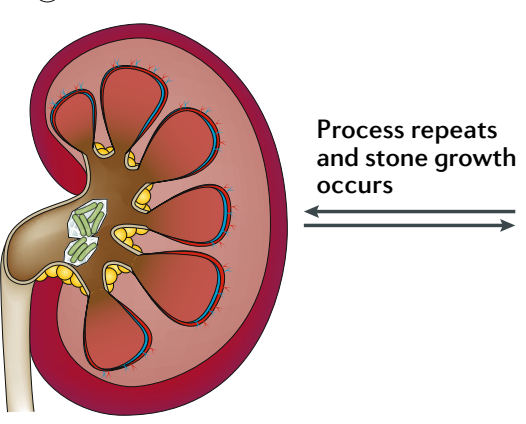
of new crystals

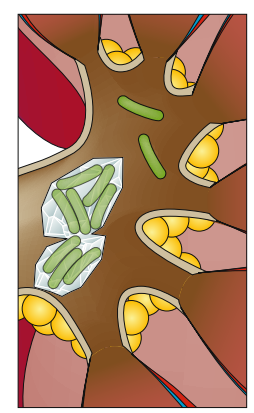

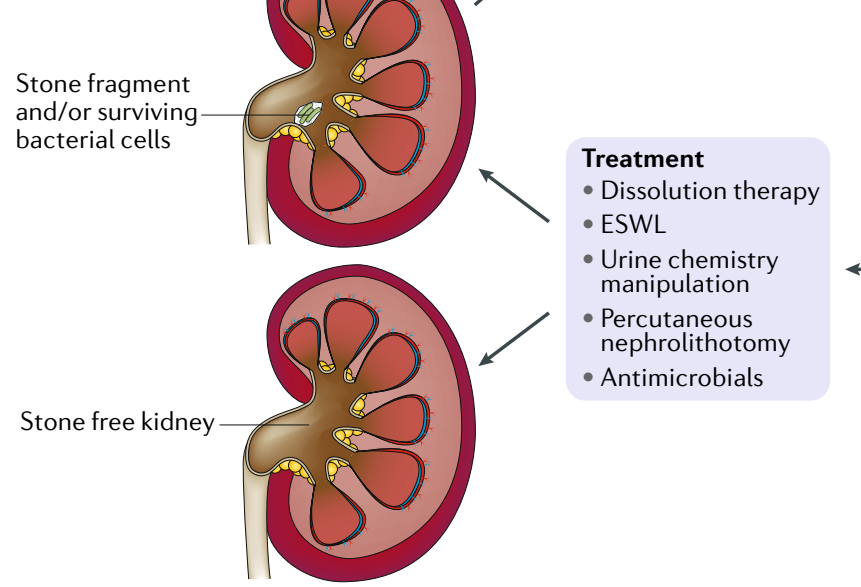

Fig. 2 | Role of microorganisms and biofilms in stone formation. Biofilm formation and struvite biomineralization seem to follow a series of steps. The first step involves the formation of a thin layer of urinary components (for example, ions, proteins, and polysaccharides) on surfaces within the urinary tract. This preconditioning film facilitates the attachment of planktonic microorganisms. Ureolysis subsequently occurs, leading to urine alkalinization and ammonium ion $\left(\mathrm{NH}_{4}^{+}\right)$ production (step 1). Next, the development of microbial microcolonies occurs and extracellular polymeric substances (EPS) are produced. During this phase, the increase in the $\mathrm{pH}$ and concentrations of $\mathrm{NH}_{4}^{+}$and carbonate ions $\left(\mathrm{CO}_{3}{ }^{2-}\right)$ can lead to the formation of microcrystals. $\mathrm{NH}_{4}^{+}$can combine with magnesium $\left(\mathrm{Mg}^{2+}\right)$ and phosphate $\left(\mathrm{PO}_{4}{ }^{3-}\right)$ ions present in urine to form struvite $\left(\mathrm{MgNH}_{4} \mathrm{PO}_{4} \cdot 6 \mathrm{H}_{2} \mathrm{O}\right) ; \mathrm{CO}_{3}{ }^{2-}$ can react with calcium $\left(\mathrm{Ca}^{2+}\right)$ and $\mathrm{PO}_{4}{ }^{3-}$ ions to produce carbapatite $\left(\mathrm{Ca}_{10}\left(\mathrm{PO}_{4}\right)_{6} \mathrm{CO}_{3}\right)$ (step 2). Crystals can form within the EPS matrix and on the surface of the forming biofilms; during this step, microbial detachment from the biofilm into the urinary tract might also occur (step 3). Crystal growth and secondary nucleation of crystals then occur within the EPS matrix, resulting in crystal formation in the biofilm. Attachment of planktonic bacteria (released from the previous step) to crystals can also occur, resulting in the formation of microcolonies and biofilm-driven crystal formation (that is, a new layer of microorganisms encased in crystals) (step 4). Finally, repetition of the previous steps results in the integration of crystals within the biofilm, leading to infection stone formation. Following treatment, stone fragments or surviving cells can remain in the urinary tract and potentially lead to recurrent microbial infections, biofilm development, and biomineralization (step 5). ESWL, extracorporeal shock wave lithotripsy.

and $20 \%$ of pure calcium phosphate stones ${ }^{114}$. The most frequently observed bacteria in calcium-based stones are E. coli and Pseudomonas spp., followed by other ureolytic microorganisms that are commonly found in struvite stones $^{113,114}$. Interestingly, an in vitro study demonstrated that $E$. coli cells could decrease urinary levels of citrate, a phenomenon that was strongly correlated with an increase in calcium precipitation, suggesting an increase in urease-induced calcium phosphate crystallization ${ }^{129}$.

Bacterial imprints in calcium-based calculi have also been documented ${ }^{130-132}$. Bazin et al. ${ }^{130}$ observed a high number of bacterial imprints in carbapatite stones, whereas no such imprints were found in struvite stones. In the case of mixed stones (for example, struvite and carbapatite), bacterial imprints were observed in small carbapatite crystals rather than large struvite crystals ${ }^{130}$. Carpentier et al. ${ }^{131}$ suggested that the presence of bacterial imprints is indicative of prior or current UTIs (both with urea-hydrolysing and non-urea-hydrolysing bacteria) associated with the formation of calcium phosphate stones. In this study, a positive correlation was observed between bacterial imprints and both the 
presence of amorphous carbonated calcium phosphate (ACCP) and a high carbonation rate (carbonate:phosphate ion ratio) in carbapatite stones devoid of struvite. According to the authors, the association of a high carbonation rate with the presence of ACCP-containing calcium phosphate stones is indicative of the involvement of ureolytic bacteria, whereas the association of a low carbonation rate with the absence of ACCP is suggestive of the involvement of nonureolytic bacteria ${ }^{131}$. In addition, the intracellular formation of calcium crystals has been reported in both ureolytic and nonureolytic bacteria isolated from human urine, which could function as additional nidi for stone formation ${ }^{133}$. Future studies should assess whether the detection of bacteria in calcium-based stones is indicative of an active role for bacteria in stone formation.

Role of microbial biofilms in stone formation. The presence of infectious microorganisms in the urinary tract can result in the formation of biofilms, for example in the urothelium or on catheters. Biofilm formation can potentially complicate renal conditions and their respective treatments, as they are generally more resistant to antimicrobials and other stress conditions than planktonic bacteria ${ }^{134}$. The resistance of biofilms is attributed to a number of factors, including: the extracellular polymeric substances (EPS) matrix, which functions as a protective barrier to entrap antimicrobials and hinder their transport into the biofilm; the physiological heterogeneity of biofilms, which creates zones with concentration gradients of nutrients, waste products, and signalling molecules, as well as zones of low metabolic activity (slow growth) that decrease the susceptibility of the biofilm to antimicrobials; adaptive microbial responses, whereby cells might be able to modify their physiological responses according to the stress created by environmental fluctuations; and the presence of persister cells, which are highly protected (spore-like) cells that can survive antimicrobial challenges ${ }^{127,134}$. Common sources of biofilms in urology include catheters (such as urethral, continuous ambulatory peritoneal dialysis, and haemodialysis catheters) and kidney stones ${ }^{135}$, which lead to diverse complications including pyelonephritis, cystitis, the development of staghorn stones, and catheter encrustation ${ }^{136}$. Aside from their established roles in UTIs and their respective complications ${ }^{135-137}$, biofilms might have specific roles in infection stone formation.

Biofilm development is suggested to be a prerequisite for struvite stone formation, given that microbially catalysed urea hydrolysis creates the appropriate conditions and that the EPS matrix might function as a nucleation site for crystal development. Biofilm formation and struvite biomineralization follows a series of steps ${ }^{136,138,139}$ (FIG. 2). The first step involves the attachment of urea-hydrolysing organisms to the urinary tract. The deposition and accumulation of urinary components (for example, ions, proteins, and polysaccharides) on a solid surface might promote the formation of a preconditioning film that facilitates bacterial adhesion by providing receptor sites ${ }^{136,138}$. Bacterial adhesion to the urothelial surface is driven by urinary chemistry and determined by the presence of bacterial fimbriae, pili, or flagella ${ }^{140}$. The importance of fimbriae in P. mirabilis colonization in bladder and kidney tissues has previously been shown in murine models ${ }^{141}$. In the early stages of colonization, a thin layer comprising mostly polysaccharides and planktonic cells is observed and is accompanied by ureolysis, which results in urine alkalinization and ammonium ion production. The second phase involves the formation of small bacterial communities known as microcolonies and the production of EPS to form a protective layer ${ }^{142}$. The microorganisms within these microcolonies continue the process of urea hydrolysis, which increases the $\mathrm{pH}$ and the concentrations of ammonium and carbonate ions leading to the formation of primary microcrystals. Third, local changes in urine $\mathrm{pH}$ at the bacterial surface result in the formation of crystals that can be subsequently entrapped in the EPS matrix ${ }^{136,138}$. Over time, this process results in the formation of - often sheet-like - microcrystalline material above the preconditioning film, followed by the accumulation of microcrystals. The detachment of bacteria from the biofilm into the urinary tract might also occur. During the fourth step, crystal growth and secondary nucleation within the EPS matrix results in crystal formation around the adherent bacteria, which causes the encasement of the bacteria within the growing stone ${ }^{136,138}$. Planktonic bacteria (potentially released during the previous step) attach to the surface of the pre-existing crystals, leading to the formation of additional microcolonies and, eventually, biofilm-driven crystal formation resulting in the formation of a new layer of bacteria encased in struvite crystals ${ }^{136,138}$. Finally, infection stone formation is driven by repeated cycles of the previous steps (attachment of planktonic cells, formation of microcolonies and biofilms, and crystal growth) to integrate crystals within the bacterial biofilm, and vice versa ${ }^{136,138}$.

One of the unique features of biofilms is the production of EPS, which form a complex matrix composed of polysaccharides, proteins, lipids, nucleic acids, and other organic compounds $\mathrm{s}^{139,143}$; the EPS matrix seems to form as a result of microbial secretions and cell lysis ${ }^{144}$. EPS matrix composition depends on the bacterial species, biofilm growth phase, solution chemistry, and the surrounding environmental conditions (such as temperature and $\mathrm{pH})^{64}$. The EPS matrix is suggested to have a number of functions, including stabilizing the biofilm structure, facilitating adhesion to surfaces, nutrient trapping or transport, promoting bacterial communication (quorum sensing), cell aggregation, and protection of the biofilm $^{63,139}$. The lack of biofilm susceptibility to antimicrobial agents has often been attributed to the protective function of the EPS matrix, which can function as a barrier to transport by entrapping solutes and limiting the penetration of antimicrobials within the biofilm ${ }^{127}$; this characteristic complicates the treatment of UTIs and the management of infection stones.

Biomineralization influences biofilm architecture and properties by affecting its primary characteristics, including permeability and morphology, as well as detachment and transport processes within the biofilm ${ }^{62,145,146}$. Ureolytic biomineralization increases biofilm mechanical stability and decreases its susceptibility 
to antimicrobials ${ }^{62}$. Under identical growth conditions, Li et al. ${ }^{146}$ characterized the biofilm formation of two types of $P$. mirabilis HI4320, urease-positive and urease-negative, and their response to exposure to the antibiotic ciprofloxacin. Urease-positive P. mirabilis biofilms were shown to be less susceptible to and more stable in the presence of antimicrobials than urease-negative biofilms, suggesting that the accumulation of minerals (such as struvite) in the urease-positive $P$. mirabilis biofilm created a transport barrier that hindered ciprofloxacin penetration ${ }^{146}$.

\section{Management}

The treatment of infection stones is particularly challenging owing to their association with infectious bacteria, complex structure (bacteria become encased within the aggregated minerals held together by the stone matrix), fast growth, and high rates of recurrence ${ }^{11}$. Infection stone treatment should start with an accurate diagnosis based on stone detection, identification, and characterization. The management of infection stones relies heavily on the use of antibiotics to treat UTIs, surgical and medical treatment that aims to completely remove the stones, and pharmacological therapies.

\section{Diagnosis}

The initial steps in the management of infection stones consist of stone detection and identification. The selection of a particular treatment depends on a number of factors, including stone location (bladder, kidney, or ureters), stone characteristics (size, composition, hardness, and porosity), patient characteristics (sex, age, general health, ethnicity, and geographic location), and lifestyle factors (such as diet).

Stone detection. Stone imaging is a crucial tool for stone diagnosis and determines the course of clinical management. Available imaging modalities include $\mathrm{CT}$, ultrasonography, radiography (plain-film X-ray and intravenous urography), and MRI ${ }^{147}$. CT is a fast and reliable technique for the detection and localization of most stone types and, accordingly, is the preferred technique for stone detection and has replaced other traditional radiography techniques. CT is readily available at most hospitals and, given its high sensitivity, its use has increased by approximately tenfold over the past two decades in the USA ${ }^{148}$. Although CT is the preferred modality for stone imaging owing to its accuracy, its use poses a risk of radiation exposure to patients; the accumulated average dose received by patients with an acute stone episode is $>50 \mathrm{mSv}$ per year ${ }^{149}$. Low-dose CT ( $<3 \mathrm{mSv}$ for the entire CT examination) has high sensitivity and specificity as an initial imaging technique for patients with suspected urolithiasis ${ }^{149,150}$. However, further improvements in the performance of low-dose CT for the detection of urolithiasis are still needed.

Ultrasonography has been suggested as the primary imaging tool alternative to CT for the diagnosis of urinary stones ${ }^{147,151}$, and is of particular importance for the detection of calculi in children, pregnant women, and recurrent stone formers. Ultrasonography markedly reduces the radiation exposure of patients, but is not as sensitive as CT and offers poor visualization of ureteral stones ${ }^{147,151}$. MRI is not commonly used for the diagnosis of urinary calculi owing to limitations in stone visualization, but the use of ultrashort echo time (UET) sequences has demonstrated sensitivity results comparable to CT imaging, suggesting the potential for the future development of UET-MRI for stone detection ${ }^{152}$.

Stone identification and characterization. The proper identification of the stone type can be crucial for successful treatment as different stone types require different stone management strategies. A wide range of techniques can be used for stone analysis on the basis of morphology, mineral composition, and the thermal, hardness, and spectral characteristics of the stones. Techniques used for stone identification and characterization vary from traditional wet and dry chemical analysis to modern techniques such as X-ray diffraction (XRD), Fourier transform infrared spectroscopy (FT-IR), Raman spectroscopy, scanning electron microscopy (SEM), and thermogravimetry ${ }^{153-155}$. Traditionally, the chemical composition of stones was determined predominantly using wet and dry chemical methods. However, these techniques are now used infrequently owing to issues with stone misidentification and the requirement for high samples quantities ${ }^{154}$. Currently, stone composition is commonly determined using XRD, FT-IR, and Raman spectroscopy. Furthermore, stone surface morphology can be characterized using SEM, although the clinical relevance of this approach might be limited ${ }^{156}$. At present, FT-IR is the preferred method for assessing the mineralogical composition of urinary stones, as it is straightforward and highly reliable.

The heterogeneity of infection stones makes the determination of stone composition very challenging; thus, careful examination of the stone sample is required. Bazin et al. ${ }^{157}$ showed the heterogeneous spatial distribution of different chemical phases along an $18 \mathrm{~mm}$ stone, from the core to its surface; ammonium urate (induced by diarrhoea), whewellite (hyperoxaluria associated with vegetal alimentation and low diuresis), and carbapatiteweddelite (associated to hypercalciuria of dietetic origin) mineral compositions were identified using FTIR spectroscopy. Fine microscopic sectioning of the stone sample is recommended to avoid the false identification of stones or missing certain mineralogies within urinary tract stones ${ }^{158}$.

The development of new tools that enable the analysis of the entire stone composition before removal and simultaneously provide information on stone structure and morphology would be an important advance in the clinical treatment paradigm. To that end, modified versions of CT have been suggested as potential methods to identify stone mineral composition before removal. Specifically, dual-energy CT has shown potential for stone identification, as it can differentiate uric acid ${ }^{159}$ and cystine ${ }^{160}$ stones from other stone types. Micro-CT, in addition to providing detailed information on stone structure, has been used to identify different mineral constituents of most types of urinary calculi - even those of mixed composition - using X-ray attenuation values $^{161,162}$. 


\section{Treatment}

The development of bacterial biofilms associated with UTIs can lead to severe urological complications, including the formation of infection stones. In addition, the formation of biofilms confers stability and decreased susceptibility to antimicrobials ${ }^{63,139}$, complicating treatment. As a result, the management of patients with infection stones has focused on reducing biofilm-related infections and developing therapies to either prevent biofilm formation or remove existing biofilms.

Different methods have been used to treat infection stones according to their size and stage of development. Management of staghorn calculi generally involves the use of antibiotics (before and after stone removal) to eliminate planktonic bacteria in the urinary tract; surgical treatment to break up stones and remove the stone fragments; dissolution therapy ${ }^{163}$ and/or urine acidification (modification of urine $\mathrm{pH}$ to avoid struvite precipitation) ${ }^{164}$; and/or pharmacological treatment (with, for example, urease inhibitors) ${ }^{138}$. Regardless of the stone removal method used, the removal of all stone fragments is important as the presence of bacteria within the stone matrix of remaining fragments can function as potential nidi for reinfection and subsequent stone recurrence ${ }^{138}$.

Antibiotics. Traditionally, the pharmacological treatment of infection stones involves the use of antibiotics, administered preoperatively and/or postoperatively. This treatment approach is designed to reduce the general risk of infection associated with surgery and to completely kill all infectious bacteria, the latter of which is specifically relevant when residual stone fragments remain in the body after stone removal. The reported multidrug resistance of many uropathogens complicates pharmacological treatment. For instance, Proteus spp. are resistant to some of the most common antibiotics, including penicillin $\mathrm{G}$, oxacillin, macrolides, lincosamides, streptogramins, glycopeptides, rifampicin, aminoglycosides, acylureidopenicillins, some cephalosporins, carbapenems, azteonam, quinolones, sulfamethoxazole, and co-trimoxazole ${ }^{165}$. Moreover, differences in natural susceptibility to antibiotics were observed between two Proteus species; P. mirabilis were more resistant to tetracyclines but more susceptible to $\beta$-lactams than P. penneri ${ }^{165}$. Owing to the range of possible effects of antimicrobials on different uropathogens, the available clinical guidelines do not have specific recommendations regarding the duration and mode of administration of antibiotic therapy ${ }^{44,166}$.

The use of antibiotics is the most common pharmacological strategy for infection stone treatment, but can lead to selective pressure and the development of antibiotic resistance ${ }^{167}$. Antibiotics are mostly effective against planktonic bacteria, but the association of bacteria with stones and their presence in biofilms generally results in a greater resistance to traditional antibiotic treatments ${ }^{127}$. Thus, the sole use of antibiotics for the treatment of infection stones might be insufficient, and should instead be considered as a complementary treatment to other management strategies, such as the complete removal of residual fragments.

In recent years, efforts have focused on the discovery and use of novel pharmacological agents that can inhibit, or at least attenuate, bacterial colonization, biofilm formation, and virulence factor production by disrupting different bacterial functions such as quorum sensing, swarming motility, and bacterial attachment (TABLE 5). Although promising results have been reported, most of these studies have been performed over short time periods only and have not considered long-term effects or the influence of the biomineralization process. O'May et al. ${ }^{144}$ tested the efficacy of cranberry derivatives as anti-swarming agents for $P$. mirabilis in urea-free medium. The swarming motility of $P$. mirabilis was found to be restricted during the first 24 hours of treatment, but this beneficial effect was lost over extended time periods ( $\sim 3$ days), resulting in enhanced biofilm development. When grown in artificial urine containing urea, $P$. mirabilis swarming motility was not detected ${ }^{144}$, an effect that was attributed to the precipitation of crystals caused by ureolysis and a resultant decrease in bacterial motility ${ }^{168}$. Further investigation of how and

\begin{tabular}{|c|c|c|c|}
\hline Inhibitor & Uropathogen & Mechanism & Refs \\
\hline $\begin{array}{l}\text { Root extract of Arctium lappa } \\
\text { (quercetin derivatives) }\end{array}$ & $\begin{array}{l}\text { Escherichia coli; Proteus mirabilis; } \\
\text { Serratia marcescens }\end{array}$ & Anti-quorum-sensing activity & 207 \\
\hline $\begin{array}{l}\text { Extract of Hyptis suaveolens } \\
\text { (fatty acids) }\end{array}$ & $\begin{array}{l}\text { Klebsiella pneumoniae; Proteus } \\
\text { vulgaris; Proteus mirabilis; Serratia } \\
\text { marcescens }\end{array}$ & Anti-quorum-sensing activity & 208 \\
\hline Cranberry derivatives & Proteus mirabilis & $\begin{array}{l}\text { Anti-swarming motility (short-term) } \\
\text { activity }\end{array}$ & 144 \\
\hline $\begin{array}{l}\text { Secondary metabolites of } \\
\text { marine Streptomyces }\end{array}$ & Serratia marcescens & $\begin{array}{l}\text { Antimicrobial and anti-swarming } \\
\text { motility activity }\end{array}$ & 209 \\
\hline Extract of Anethum graveolens & Serratia marcescens & Anti-quorum-sensing activity & 210 \\
\hline $\begin{array}{l}\text { Extract of Chamaemelum } \\
\text { nobile }\end{array}$ & Pseudomonas aeruginosa & $\begin{array}{l}\text { Anti-quorum-sensing and } \\
\text { antimicrobial activity }\end{array}$ & 211 \\
\hline Extract of garlic (allicin) & Proteus mirabilis & $\begin{array}{l}\text { Anti-urease and anti-biofilm- } \\
\text { development activity }\end{array}$ & 212 \\
\hline Vanillic acid & Proteus mirabilis & $\begin{array}{l}\text { Anti-urease and antimicrobial } \\
\text { activity }\end{array}$ & 169 \\
\hline
\end{tabular}


when $P$. mirabilis swarming occurs in the context of UTIs could improve the understanding of $P$. mirabilis motility, and could, therefore, be useful for the development of anti-swarming agents.

Urease inhibitors. A common therapeutic strategy against infection stones is the complementation of antibiotic treatment with urease inhibitors. The use of urease inhibitors is recommended in patients for whom surgical intervention is contraindicated or those with recurrent infections even after stone removal ${ }^{44,166}$. Urease inhibitors are divided in substrate-like (urea) analogues (for example, hydroxyurea, thiourea, methylurea, acetohydroxamic acid, and phosphotriamides) and inhibitors that affect the mechanism of reaction (for example, phosphorodiamidates and imidazoles) ${ }^{169}$. The development of novel enzyme inhibitors might be of crucial importance due to the limitations of current urease inhibitors, such as associated adverse effects ${ }^{170}$. The use of plant metabolites (for example, diterpenoids, triterpenoids, phenols, phenolic acids, stilbenes, catechins, flavones, coumarins, alkaloids, quinones, sphingolipids, and sulfur compounds) that inhibit urease directly has proved promising, but their use is also limited by adverse effects, toxicity, and instability $^{170}$ (TABLE 5). An ideal treatment strategy would involve the development of pharmacological agents (including antibiotics, inhibitors of microbial activity and microbial attachment, as well as urease inhibitors) that, when used concurrently, would prevent swarming motility in the long term, hinder biofilm formation, inhibit urease activity, kill planktonic and biofilm-associated bacteria, and have a favourable adverse effect profile.

Break-up and removal of stone fragments. For renal or ureteral stones that cause obstruction, pain, or recurrent infections, the most common treatment options include extracorporeal shock wave lithotripsy (ESWL), anatrophic nephrolithotomy, ureteroscopy with laser lithotripsy or percutaneous nephrolithotomy (PCNL). These treatments are often combined with dietary modifications or pharmacological treatments to minimize the risk of recurrent stone disease and stone growth ${ }^{171}$. For patients who are poor candidates for surgery, dissolution therapy (for example, percutaneous chemolysis) has been used as a second-line therapy owing to the requirement for careful monitoring of patients and the need for indwelling nephrostomy tubes in the long-term to accomplish chemolysis.

ESWL is a minimally invasive, nonsurgical intervention that involves the use of external energy to destroy stones, enabling stone fragments to pass through the urinary tract. Success rates for this procedure are dependent on a number of different patient factors, including body habitus (that is, stone-to-skin distance) and stone composition, size, and location ${ }^{166,172,173}$. ESWL is recommended for the treatment of struvite stones due to their relative softness compared to other stone types (TABLE 2), but it is limited to the treatment of small stones $(<2 \mathrm{~cm})^{174}$.

Ureteroscopy is an endoscopic procedure performed using a transurethral approach; typically, a semirigid ureteroscope is used for treatment of lower ureteral stones in males and both lower and some upper ureteral stones in females, whereas a flexible ureteroscope is used for proximal ureteral stones and renal stones in both males and females ${ }^{175}$. During ureteroscopy, a Holmium:yttrium-aluminium-garnet (YAG) laser is used to fracture stones ${ }^{176}$, which can either be basket-extracted or 'dusted' into tiny particles that have a high probability of urinary passage. Compared with ESWL, the main advantage of ureteroscopic treatment of stones is the higher stone-free rate achieved ${ }^{175}$. Moreover, the success of ureteroscopy is not limited by body habitus, and it can be performed safely in patients with bleeding diathesis or coagulopathy with minimal risk of haemorrhage or transfusion ${ }^{177}$.

PCNL is reserved for the treatment of large stones (typically renal stones), including stones $>20 \mathrm{~mm}$ as well as larger branched (staghorn) calculi. PCNL is performed by placing a sheath percutaneously through the flank into the renal collecting system, with radiographic guidance (ultrasonography or fluoroscopy) ${ }^{178}$. A rigid endoscope can then be inserted into this sheath, and stones can be fractured with laser, ultrasound, or pneumatic energy before removal. PCNL has been historically performed using a $30 \mathrm{Fr}$ percutaneous access sheath. However, attempts to miniaturize the access sheath have resulted in the development of PCNL modifications and, currently, PCNL is performed through a wide range of access sheaths (5-30 Fr) ${ }^{179-181}$. PCNL is associated with the highest postoperative stone-free rates compared to retrograde intrarenal surgery ${ }^{182}$, but also carries risk of complications. Although rates of major complications are low ( $9 \%$ of complications are >Clavien grade II, which require pharmacological treatment ${ }^{183}$ ), they can include infection and/or sepsis, bleeding requiring transfusion, and injury to surrounding structures (spleen, liver, colon, or pleura $)^{184}$. Significant postoperative bleeding has been reported to occur in $0.5-5 \%$ of patients ${ }^{178}$.

Anatrophic nephrolithotomy is a surgical procedure for the removal of complex staghorn stones through a flank incision ${ }^{185}$. This procedure is recommended when the success of staghorn calculi removal is estimated to be unlikely following a number of treatments using PCNL or ESWL ${ }^{44}$; for example, in patients with obesity and anatomical abnormalities ${ }^{185}$. Anatrophic nephrolithotomy is an invasive procedure that requires a longer recovery time than endoscopic procedures. However, this procedure achieves stone clearance rates of $80-100 \%$ without the need for secondary interventions ${ }^{186}$. Robotic-assisted laparoscopic anatrophic nephrolithotomy has been reported to minimize postoperative stay and expedite recovery, while preserving renal function ${ }^{186}$.

In 2016, the AUA and Endourological Society published joint guidelines for the surgical management of stone disease ${ }^{166}$, which included a number of key points of relevance to infection stones (BOX 2).

\section{Multidisciplinary approach to management}

As many factors influence the development of infection stones, understanding the composition, structure, and physical properties of stones as well as their interrelationships is crucial to determine the appropriate medical treatment. Thus, the development of future strategies for 


\section{Box 2 | Guidelines for the surgical management of stone disease}

In 2016, the American Urological Association (AUA) and Endourological Society published joint guidelines for the surgical management of stone disease ${ }^{166}$.

- For ureteral stones, ureteroscopy is the procedure with the highest stone-free rate and should be offered as first-line therapy for patients with distal and mid-ureteral stones.

- For ureteral stones, ESWL is an acceptable alternative to ureteroscopy, which is less invasive but also associated with lower stone-free rates.

- For symptomatic non-lower pole renal stones $\leq 20 \mathrm{~mm}$, ESWL or ureteroscopy are acceptable options; for stones $>20 \mathrm{~mm}$, PCNL is recommended as first-line therapy followed by ureteroscopy.

- For symptomatic lower pole stones $\leq 10 \mathrm{~mm}$, ESWL or ureteroscopy are acceptable options; for stones $>10 \mathrm{~mm}$, PCNL or ureteroscopy are first-line therapies.

- If infection stones are diagnosed or suspected (struvite stone or other stones associated with recurrent infection or bacterial colonization), clinicians should offer patients endoscopic procedures to render the patients stone-free and, therefore, limit the possibility of further stone growth, recurrent infection, and renal damage.

\section{Reactive transport}

modelling

Computer models that

integrate the use of chemical

reactions with the transport of

fluids.

Geochemical modelling software

Computer models that use thermodynamics and/or kinetics to analyse chemical reactions that affect geological systems. stone diagnosis and treatment should rely on an interdisciplinary approach involving: the elucidation of the key mechanisms of stone formation (nucleation, crystal growth, aggregation, and association with microorganisms); the proper identification and characterization (quantitative and qualitative) of stones, including chemical composition (organic and inorganic) and microstructure; assessment of stone microbiology and the influence of biofilm formation on stone formation; and investigation of the hydrodynamics and reactive transport in the urinary tract that can influence stone formation.

Medical treatments have traditionally been developed on the basis of clinical observations (for example, patient response), which do not usually provide a deep understanding of the basic mechanisms of stone formation and the microorganism-fluid-mineral interactions involved. Well-designed laboratory experiments (in vitro) combined with computational simulations (in silico) can enable the study of the key processes involved in stone formation at the spatial and temporal resolution required to elucidate microorganism-mineral interactions. This could lead to an understanding that could be exploited to develop novel treatments that target and prevent this important step in infection stone formation.

Various study systems have been used to identify the individual and combined effects of different parameters on infection stone formation. Batch experiments (in vitro) have been performed to evaluate the effect of modulators (inhibitors and promoters) on the crystallization of struvite (TABLE 3), study inhibitors of uropathogen colonization and/or biofilm formation (TABLE 5), and assess the resistance of stent materials to encrustation $^{187,188}$. However, batch experiments have a number of disadvantages, including limitations in their ability to simulate the flow conditions of the urinary tract system and for long-term and real-time evaluation. The use of flow systems to study infection stone formation is promising, as they can model the hydraulic conditions in the urinary tract for extended periods of time. For instance, the Center for Disease Control (CDC) biofilm reactor ${ }^{158}$ has been described to yield valuable and reproducible results related to the encrustation of urological device materials ${ }^{189}$. This reactor enables the growth of bacterial biofilms on removable coupons under controlled conditions to evaluate the effects of bacterial species, modulators of struvite crystallization, and urine chemistry on biomineralization. Other systems have been developed to study the process of encrustation of different materials used in urinary tract devices (for example, silicon, polyurethane, and Percuflex ${ }^{190,191}$. Hobbs et al. ${ }^{192}$ developed an in vitro system that simulates the urinary tract system using CDC biofilm reactors as kidney and bladder analogues, tubing to simulate the ureter line, and sponge coupons to simulate the porous structure of the kidneys. This system enables the real-time monitoring of bacterial biofilm formation and ureolysis, which can lead to the precipitation of struvite and other minerals that comprise infection stones.

Biomineralization in the urinary tract is a complex multifactorial process. Thus, its investigation and simulation should consider the influence of factors such as reaction (ureolysis and precipitation), transport (advection and diffusion), and hydrodynamics (flow characteristics and shear stress), as well as the mechanics and viscoelasticity of the developing biofilm-mineral conglomerates. In silico modelling can be used as an extension of controlled laboratory experiments. With the aid of modern software, reactive transport modelling enables the analysis of coupled physical, chemical, and biological processes in defined systems ${ }^{193}$. For instance, by using laboratory experiments to grow E. coli MJK2 biofilms in the presence of urea and by measuring the characteristics of the developed biofilm, Connolly et al ${ }^{194}$ used COMSOL Multiphysics software (a finite element framework; COMSOL Inc., Burlington, MA, USA) to determine the kinetic coefficients of bacterial urea hydrolysis in the biofilm. Determination of biofilm-specific reaction rates can provide accurate microscale modelling of biofilm systems and, therefore, have potential applications in systems such as urethral catheters ${ }^{195}$.

In silico modelling using geochemical modelling software can also aid in the assessment of the risk of crystal precipitation in complex liquids (such as urine) by predicting the saturation state of the solution ${ }^{196}$. Several computer models can predict the chemical speciation and saturation index of a solution; for example, Visual MINTEQ ${ }^{197}$ and PHREEQC ${ }^{196}$ for geochemical problems, or EQUIL93 (REF. ${ }^{198}$ ) for evaluating urinary stone risks. Furthermore, the integration of different modelling tools can provide a more thorough description of a system than either method alone; for instance, the coupling of COMSOL and PHREEQC ${ }^{199}$ can not only provide chemical speciation information but can also describe the hydrodynamic changes in the urinary tract that occur during biofilm and urinary stone development.

\section{Conclusions}

Infection stone formation is a complex multifactorial process driven by urine chemistry, the urine microenvironment, the presence of substances that modulate (promote or inhibit) crystallization, and the association with microorganisms. Owing to the heterogeneity of stones, 
the selection of a treatment or prevention strategy depends on stone composition, location, patient characteristics and lifestyle, and the availability of treatment methods. The future of diagnosis, prevention, and treatment of infection stones should take a multidisciplinary approach that targets specific mechanisms of crystal formation and growth, which can be best accomplished through the close collaboration of basic scientists, engineers, and clinicians. Specifically, stone diagnosis and treatment strategies should rely on the proper identification and characterization of stones, elucidation of stone formation mechanisms, and determination of the microbiology of stones and the associated influence of microorganisms and their metabolic byproducts on stone characteristics.

Urine chemistry (such as supersaturation of specific components) is one of the major drivers of stone formation. However, our ability to predict the likelihood of stone formation remains limited, particularly because the urine chemistries of stone formers and non-stoneformers are not always clearly different. Little is known about the effect of urine chemistry on infection stone formation. Further studies should focus on investigating how urine chemistry influences bacterial survival, biofilm development in the urinary tract, and the formation and growth of crystals to form infection stones. The use of geochemical and reactive transport models could yield insights into which components of urine influence the initial precipitation of minerals and could, therefore, provide opportunities to manipulate urine chemistry for medical treatment.

The stone matrix seems to have an important role in the stone formation process and, moreover, the stone matrix composition influences the physical characteristics of the stones (for example, hardness). Further studies aimed at elucidating the specific mechanisms of stone growth should focus on characterizing the specific interactions between the inorganic fraction of the stone and the organic macromolecules that comprise the stone matrix. Such studies would provide a comprehensive understanding of the mechanisms and processes driving stone formation and would, therefore, support the development of treatments that inhibit the aggregation of stones. Given that multiple mechanisms probably influence stone formation, successful prevention and treatment strategies should comprise multiple pharmacological compounds or treatment approaches, each targeting a specific mechanism.

Infection stones are commonly associated with UTIs as a result of biomineralization by urease-hydrolysing microorganisms. Moreover, the development of microbial biofilms complicates renal conditions and treatments owing to the inherent resistance of biofilms to antimicrobials and stress conditions. Although the biomineralization process seems to influence the physical properties and resistance of biofilms, the specific interactions underpinning this observation have not yet been established. Further research should address this gap in knowledge by assessing the mechanisms that control precipitation and the overall accumulation of mineral deposits in biofilms, determining the spatial patterns of mineral formation in biofilms, and establishing the influence of biofilm development on mineralization, and vice versa. However, improved experimental and computational models, as well as novel prototypes and approaches that enable nondestructive real-time observations, will be necessary to assess the complex biofilm-mineral interactions.

Published online: 23 November 2018
1. Pearle, M. S., Calhoun, E. A. \& Curhan, G. C. Urological diseases in America project: urolithiasis. J. Urol. 173, 848-857 (2005).

2. Saigal, C. S., Joyce, G. \& Timilsina, A. R. Direct and indirect costs of nephrolithiasis in an employed population: opportunity for disease management? Kidney Int. 68, 1808-1814 (2005).

3. Foster, G., Stocks, C. \& Borofsky, M. S. Emergency department visits and hospital admissions for kidney stone disease, 2009: statistical brief \#139. NCBI https://www.ncbi.nlm.nih.gov/books/NBK100827/ (2012).

4. Romero, C. V., Akpinar, H. \& Assimos, D. G. Kidney stones: a global picture of prevalence, incidence and associated risk factors. Rev. Urol. 12, e86-e96 (2010).

5. Brikowski, T. H., Lotan, Y. \& Pearle, M. S Climate-related increase in the prevalence of urolithiasis in the United States. Proc. Natl Acad. Sci. USA 105, 9841-9846 (2008).

6. Scales, Jr, C. D., Smith, A. C., Hanley, J. M. $\&$ Saigal, C. S. Prevalence of kidney stones in the United States. Eur Urol 62, 160-165 (2012).

7. Becker, G. The CARI guidelines. Kidney stones: uric acid stones. Nephrology 12 (Suppl. 1), 21-25 (2007).

Becker, G. The CARI guidelines. Kidney stones: cystine stones. Nephrology 12 (Suppl. 1), 4-10 (2007).

9. Evan, A. P. Physiopathology and etiology of stone formation in the kidney and the urinary tract. Pediatr. Nephrol. 25, 831-841 (2010).

10. Parmar, M. S. Kidney stones. BMJ 328, 1420-1424 (2004).

11. Bichler, K. H. et al. Urinary infection stones. Int. J. Antimicrob. Agents 19, 488-498 (2002).

12. Doyle, J. D. \& Parsons, S. A. Struvite formation, control and recovery. Wat. Res. 36, 3925-3940 (2002).
13. Griffith, D. P. Struvite stones. Kidney Int. 13, 372-382 (1978).

14. Prywer, J. \& Olszynski, M. Bacterially induced formation of infectious urinary stones: recent developments and future challenges. Curr. Med. Chem. 24, 292-311 (2017)

15. Resnick, M. Evaluation and management of infection stones. Urol. Clin. North Am. 8, 265-276 (1981)

16. Schultz, L. N., Connolly, J., Lauchnor, E., Hobbs, T. A. $£$ Gerlach, R. in The Role of Bacteria in Urology (eds Lange, D. \& Chew, B.) 41-49 (Springer International Publishing, 2016).

17. Trinchieri, A., Curhan, G., Karlsen, S. \& Wu, K. J. in Proceedings of $1 \mathrm{st}$ International Consultation on Stone Disease (eds Segura, J., Conort, P. \& Khoury, S.) 13 (Editions 21, Paris, 2003).

18. Worcester, E. M. \& Coe, F. L. Nephrolithiasis. Prim. Care 35, 369-391 (2008)

19. Hodgkinson, A. \& Pyrah, L. N. The urinary excretion of calcium and inorganic phosphate in 344 patients with calcium stone of renal origin. Br. J. Surg. 46, 10-18 (1958).

20. Chow, K., Dixon, J., Gilpin, S., Kavanagh, J. P. $\&$ Rao, P. N. Citrate inhibits growth of residual fragments in an in vitro model of calcium oxalate renal stones. Kidney Int. 65, 1724-1730 (2004).

21. Asplin, J. R. Hyperoxaluric calcium nephrolithiasis. Endocrinol. Metab. Clin. North Am. 31, 987-949 (2002).

22. Robertson, W. G., Peacock, M., Heyburn, P. J., Marshall, D. H. ¿ Clark, P. B. Risk factors in calcium stone disease of the urinary tract. Br. J. Urol. 50, 449-454 (1978)

23. Parks, J. H., Coe, F. L., Evan, A. P. \& Worcester, E. M. Urine $\mathrm{pH}$ in renal calcium stone formers who do and do not increase stone phosphate content with time. Nephrol. Dial. Transplant. 24, 130-136 (2009).
24. Parks, J. H., Worcester, E. M., Coe, F. L., Evan, A. P. \& Lingeman, J. E. Clinical implications of abundant calcium phosphate in routinely analyzed kidney stones. Kidney Int. 66, 777-785 (2004).

25. Daudon, M., Bouzidi, H. \& Bazin, D. Composition and morphology of phosphate stones and their relation with etiology. Urol. Res. 38, 459-467 (2010).

26. Wagner, C. A. \& Mohebbi, N. Urinary pH and stone formation. J. Nephrol. 23, S165-S169 (2010).

27. Daudon, M. et al. Sex- and age-related composition of 10617 calculi analyzed by infrared spectroscopy. Urol. Res. 23, 319-326 (1995).

28. Sakhaee, K., Adams-Huet, B., Moe, O. W. \& Pak, C. Y. C. Pathophysiologic basis for normouricosuric uric acid nephrolithiasis. Kidney Int. 62, 971-979 (2002).

29. Halabe, A. \& Sperling, O. Uric acid nephrolithiasis. Miner. Electrolyte Metab. 20, 424-431 (1994).

30. Ahmed, K., Dasgupta, P. \& Khan, M. S. Cystine calculi: challenging group of stones. Postgrad. Med. J. 82, 799-801 (2006).

31. Daudon, M. \& Jungers, P. in Urinary Tract Stone Disease (eds Rao, N. P., Preminger, G. M. ¿ Kavanagh, J. P.) 225-237 (Springer London, 2011).

32. Yarlagadda, S. G. \& Perazella, M. A. Drug-induced crystal nephropathy: an update. Expert Opin. Drug Saf. 7, 147-158 (2008).

33. Cohen, T. D \& Preminger, G. M. Struvite calculi. Semin. Nephrol. 16, 425-434 (1996).

34. Lerner, S. P., Gleeson, M. J. \& Griffith, D. P. Infection stones. J. Urol. 141, 753-758 (1989).

35. Singh, M., Chapman, R., Tresidder, G. C. \& Blandy, J. The fate of the unoperated staghon calculus. BJU Int. 45, 581-585 (1973)

36. Deutsch, P. G. \& Subramonian, K. Conservative management of staghorn calculi: a single-centre experience. BJU Int. 118, 444-450 (2016). 
37. Knoll, T. et al. Urolithiasis through the ages: data on more than 200,000 urinary stone analyses. J. Urol. 185, 1304-1311 (2011).

38. Stasinou, T., Bourdoumis, A. \& Masood, J. Forming a stone in pelviureteric junction obstruction: cause or effect? Int. Braz. J. Urol. 43, 13-19 (2017).

39. Becknell, B. et al. Struvite urolithiasis and chronic urinary tract infection in a murine model of urinary diversion. Urology 81, 943-948 (2013)

40. Becknell, B., Mohamed, A. Z., Li, B., Wilhide, M. E. \& Ingraham, S. E. Urine stasis predisposes to urinary tract infection by an opportunistic uropathogen in the megabladder (Mgb) mouse. PLOS ONE 10, e0139077 (2015).

41. Dorsher, P. T. \& McIntosh, P. M. Neurogenic bladder Adv. Urol. 2012, 16 (2012).

42. Stickler, D. J. Clinical complications of urinary catheters caused by crystalline biofilms: something needs to be done. J. Int. Med. 276, 120-129 (2014).

43. Lieske, J. C. et al. Diabetes mellitus and the risk of urinary tract stones: a population-based case-contro study. Am. J. Kidney Dis. 48, 897-904 (2006).

44. Preminger, G. M. et al. AUA guideline on management of staghorn calculi: diagnosis and treatment recommendations. J. Urol. 173, 1991-2000 (2005).

45. Iqbal, M. W. et al. Contemporary management of struvite stones using combined endourologic and medical treatment: predictors of unfavorable clinical outcome. J. Endourol. 30, 771-777 (2016).

46. Lingeman, J. E., Siegel, Y. I. \& Steele, B. Metabolic evaluation of infected renal lithiasis: clinical relevance. J. Endourol. 9, 51-54 (1995).

47. Flannigan, R. K. et al. Evaluating factors that dictate struvite stone composition: a multi-institutional clinica experience from the EDGE Research Consortium. Can. Urol. Assoc. J. 12, 131-136 (2018).

48. Iqbal, M. W. et al. Should metabolic evaluation be performed in patients with struvite stones? Urolithiasis 45, 185-192 (2017).

49. Boyce, W. H. Organic matrix of human urinary concretions. Am. J. Med. 45, 673-683 (1968)

50. Boonla, C., Youngjermchan, P., Pumpaisanchai, S., Tungsanga, K. \& Tosukhowong, P. Lithogenic activity and clinical relevance of lipids extracted from urines and stones of nephrolithiasis patients. Urol. Res. 39 9-19 (2011).

51. Roberts, S. \& Resnick, M. Glycosaminoglycans content of stone matrix. J. Urol. 135, 1078-1083 (1986).

52. Khan, S. R., Glenton, P. A., Backvov, R. \& Talham, D. R. Presence of lipids in urine, crystals and stones: implications for the formation of kidney stones. Kidney Int. 62, 2062-2072 (2002)

53. lida, S. et al. Analysis of matrix glycosaminoglycans (GAGs) in urinary stones by high-performance liquid chromatography. Scann. Microsc. 13, 173-181 (1999).

54. Nishio, S. et al. Matrix glycosaminoglycan in urinary stones. J. Urol. 134, 503-505 (1985).

55. Gilbert, P. U. P. A. The organic-mineral interface in biominerals. Rev. Miner. Geochem. 59, 157-185 (2005).

56. Chen, L. et al. Seed-mediated synthesis of unusual struvite hierarchical superstructures using bacterium. Cryst. Growth Des. 10, 2073-2082 (2010).

57. Prywer, J. \& Torzewska, A. Bacterially induced struvite growth from synthetic urine: experimental and theoretical characterization of crystal morphology. Cryst. Growth Des. 9, 3538-3543 (2009).

58. Prywer, J. \& Torzewska, A. Biomineralization of struvite crystals by Proteus mirabilis from artificial urine and their mesoscopic structure. Cryst. Res. Technol. 45 1283-1289 (2010)

59. Prywer, J., Torzewska, A. \& Plocinski, T. Unique surface and internal structure of struvite crystals formed by Proteus mirabilis. Urol. Res. 40, 699-707 (2012).

60. Sadowski, R. R., Prywer, J. \& Torzewska, A. Morphology of struvite crystals as an evidence of bacteria mediated growth. Cryst. Res. Technol. 49, 478-489 (2014)

61. Sun, J. et al. Synthesis of struvite crystals by using bacteria Proteus mirabilis. Synt. React. Inorg. M. 42. 445-448 (2012)

62. $\mathrm{Li}, \mathrm{X}$. et al. In situ biomineralization and particle deposition distinctively mediate biofilm susceptibility to chlorine. Appl. Environ. Microbiol. 82, 2886-2892 (2016).

63. Sutherland, I. W. Biofilm exopolysaccharides: a strong and sticky framework. Microbiology 147, 3-9 (2001).

64. Tourney, J. \& Ngwenya, B. T. The role of bacterial extracellular polymeric substances in geomicrobiology. Chem. Geol. 386, 115-132 (2014).
65. Ringdén, I. \& Tiselius, H.-G. Composition and clinically determined hardness of urinary tract stones. Scand. J. Urol. Nephrol. 41, 316-323 (2007).

66. Zhong, P., Chuong, C. J. \& Preminger, G. M. Characterization of fracture toughness of renal calculi using a microindentation technique. J. Mat. Sci. Lett. 12, 1460-1462 (1993)

67. Kohri, K. et al. Biomolecular mechanism of urinary stone formation involving osteopontin. Urol. Res. 40, 623-637 (2012)

68. Piechota, J., Prywer, J. \& Torzewska, A. Ab initio predictions of structural and elastic properties of struvite: contribution to urinary stone research. Comput. Methods Biomech. Biomed. Engin. 15 1329-1336 (2012).

69. Strakosha, R., Monga, M. \& Wong, M. Y. C. The relevance of Randall's plaques. Indian J. Urol. 30 49-54 (2014)

70. Jaeger, C. D. et al. Endoscopic and pathologic characterization of papillary architecture in struvite stone formers. Urology 90, 39-44 (2016).

71. Evan, A. P. et al. Mechanism of formation of human calcium oxalate renal stones on Randall's Plaque. Anat. Rec. 290, 1315-1323 (2007).

72. Coe, F. L., Evan, A. P., Worcester, E. M. \& Lingeman, J. E. Three pathways for human kidney stone formation. Urol. Res. 38, 147-160 (2010).

73. Bouropoulos, N. C. \& Koutsoukos, P. G. Spontaneous precipitation of struvite from aqueous solutions. J. Cryst. Growth 213, 381-388 (2000).

74. Khan, S. R. Renal tubular damage/dysfunction: key to the formation of kidney stones. Urol. Res. 34, 86-91 (2006).

75. Liu, X. Y. Heterogeneous nucleation or homogeneous nucleation? J. Chem. Phys. 112, 9949-9955 (2000)

76. Finlayson, B. \& Reid, F. The expectation of free and fixed particles in urinary stone disease. Invest. Urol. 15, 442-448 (1978)

77. Prywer, J., Mielniczek-Brzóska, E. \& Olszynski, M Struvite crystal growth inhibition by trisodium citrate and the formation of chemical complexes in growth solution. J. Cryst Growth 418, 92-101 (2015).

78. Wierzbicki, A., Sallis, J. D., Stevens, E. D., Smith, M $\Sigma$ Sikes, C. S. Crystal growth and molecular modeling studies of inhibition of struvite by phosphocitrate. Calcif. Tissue Int. 61, 216-222 (1997).

79. McLean, R. J. C. \& Nickel, J. C. Glycosaminoglycans and struvite calculi. World J. Urol. 12, 49-51 (1994).

80. Torzewska, A. \& Rozalski, A. In vitro studies on the role of glycosaminoglycans in crystallization intensity during infectious urinary stones formation. APMIS 122, 505-511 (2014).

81. De Yoreo, J. J. \& Vekilov, P. G. Principles of crystal nucleation and growth. Rev. Min. Geochem. 54 57-93 (2003)

82. Aggarwal, K. P., Narula, S., Kakkar, M. \& Tandon, C. Nephrolithiasis: molecular mechanism of renal stone formation and the critical role played by modulators. Biomed. Res. Int. 2013, 292953 (2013).

83. Fleisch, H. Inhibitors and promoters of stone formation. Kidney Int. 13, 361-371 (1978).

84. Vermeulen, C. \& Lyon, E. Mechanisms of genesis and growth of calculi. Am. J. Med. 45, 684-691 (1956)

85. He, J. Y., Deng, S. P. \& Ouyang, J. M. Morphology, particle size distribution, aggregation, and crystal phase of nanocrystallites in the urine of healthy persons and lithogenic patients. IEEE Trans. Nanobioscience 9, 156-163 (2010).

86. Prywer, J., Sadowski, R. R. \& Torzewska, A Aggregation of struvite, carbonate apatite, and Proteus mirabilis as a key factor of infectious urinary stone formation. Cryst. Growth Des. 15, 1446-1451 (2015).

87. Witzmann, F. A. et al. Label-free proteomic methodology for the analysis of human kidney stone matrix composition. Proteome Sci. 14, 4 (2016).

88. Khan, S. R., Shevock, P. N. \& Hackett, R. L. Presence of lipids in urinary stones: results of preliminary studies. Calcif. Tissue Int. 42, 91-96 (1988).

89. Boyce, W. H. in Urolithiasis - Physical Aspects: Proceedings of a Conference (eds Finlayson, B., Hench L. L. \& Smith, L. H.) 97 (National Academy of Sciences, Washington, 1972)

90. Boskey, A. L., Bullough, P. G., Vigorita, V. \& di Carlo, E. Calcium-acidic phospholipid-phosphate complexes in human hydroxyapatite-containing pathologic deposits. Am. J. Pathol. 133, 22-29 (1988).

91. Boskey, A. L. The rote of calcium-phospholipidphosphate complexes in tissue mineralization. Metab. Bone Dis. Relat. Res. 1, 137-142 (1978).

92. Khan, S. R., Shevock, P. N. \& Hackett, R. L. In vitro precipitation of calcium oxalate in the presence of whole matrix or lipid components of the urinary stones. J. Urol. 139, 418-422 (1988).

93. Boonla, C. et al. Inflammatory and fibrotic proteins proteomically identified as key protein constituents in urine and stone matrix of patients with kidney calculi. Clin. Chim. Acta 429, 81-89 (2014).

94. Merchant, M. L. et al. Proteomic analysis of renal calculi indicates an important role for inflammatory processes in calcium stone formation. Am. J. Physiol. Renal Physiol. 295, F1254-F1 258 (2008).

95. Canales, B. K. et al. Proteome of human calcium kidney stones. Urology 76, 1017.e13-1017.e20 (2010).

96. Jou, Y.-C. et al. Proteomic study of renal uric acid stone. Urology 80, 260-266 (2012)

97. Kaneko, K. et al. Comparison of matrix proteins in different types of urinary stone by proteomic analysis using liquid chromatography-tandem mass spectrometry. Int. J. Urol. 19, 765-772 (2012).

98. Kaneko, K. et al. Proteomic analysis after sequential extraction of matrix proteins in urinary stones composed of calcium oxalate monohydrate and calcium oxalate dihydrate. Anal. Sci. 31, 935-942 (2015).

99. Goldberg, J. M. \& Cotlier, E. Specific isolation and analysis of mucopolysaccharides (glycosaminoglycans) from human urine. Clin. Chim. Acta 41, 19-27 (1972).

100. McLean, R., Lawrence, J. R., Korber, D. R. $\&$ Caldwell, D. E. Proteus mirabilis biofilm protection against struvite crystal dissolution and its implications in struvite urolithiasis. J. Urol. 146, 1138-1142 (1991).

101. Poon, N. W. \& Gohel, M. D. Urinary glycosaminoglycans and glycoproteins in a calcium oxalate crystallization system. Carbohydr. Res. 347 64-68 (2012)

102. Sun, X. et al. Analysis of total human urinary glycosaminoglycan disaccharides by liquid chromatography-tandem mass spectrometry. Anal. Chem. 87, 6220-6227 (2015).

103. Yamaguchi, S. et al. Heparan sulfate in the stone matrix and its inhibitory effect on calcium oxalate crystallization. Urol. Res. 21, 187-192 (1993).

104. Michelacci, Y. M., Glashan, R. Q. \& Schor, N. Urinary excretion of glycosaminoglycans in normal and stone forming subjects. Kidney Int. 36, 1022-1028 (1989).

105. Frankel, R. B. \& Bazylinski, D. A. Biologically induced mineralization by bacteria. Rev. Miner. Geochem. 54, 95-114 (2003)

106. Bazylinski, D. A. \& Frankel, R. B. Biologically controlled mineralization in prokaryotes. Rev. Miner. Geochem. 54, 217-247 (2003).

107. Barr-Beare, E. et al. The Interaction between Enterobacteriaceae and calcium oxalate deposits. PLOS ONE 10, e0139575 (2015).

108. Dukic, I. et al. Pd8-04 transmogrifying infection stones: are calcium stones now the commoner infection stones in Pcnl? [abstract PD8-04]. J. Urol. 193, e191 (2015).

109. Romanova, Y. M. et al. Microbial communities on kidney stones. Mol. Genet. Microbiol. Virol. 30 78-84 (2015).

110. Maier, A. et al. Bacteriological evaluation of the non-struvite nephrolithiasis and its association with urinary tract infections. Rev. Rom. Med. Lab. 23 457-467 (2015)

111. Sohshang, H., Singh, M., Singh, N. \& Singh, S Biochemical and bacteriological study of urinary calculi. J. Commun. Dis. 32, 216-221 (2000).

112. Lewi, H. J. E., White, A., Hutchinson, A. G. $\&$ Scott, R. The bacteriology of the urine and renal calculi. Urol. Res. 12, 107-109 (1984).

113. Thompson, R. \& Stamey, T. Bactriology of infected stones. Urology 2, 627-633 (1973).

114. Golechha, S. ¿ Solanki, A. Bacteriology and chemical composition of renal calculi accompanying urinary tract infection Indian J. Urol 17, 111-117 (2001).

115. O'Kane, D., Kiosoglous, A. \& Jones, K. Candida dubliniensis encrustation of an obstructing upper renal tract calculus. BMJ Case Rep. 2013 bcr2013009087 (2013).

116. Wachsmuth, I. K., Davis, B. R. \& Allen, S. D. Ureolytic Escherichia coli of human origin: serological, epidemiological, and genetic analysis. J. Clin. Microbiol. 10, 897-902 (1979).

117. Parsons, C. L. The role of the glycosaminoglycan layer in bladder defense mechanisms and interstitial cystitis. Int. Urogynecol. J. 4, 373-379 (1993).

118. Khan, S. R. Histological aspects of the "fixed-particle" model of stone formation: animal studies. Urolithiasis 45, 75-87 (2016). 
119. Chen, X. e., Ling, P., Duan, R. \& Zhang, T. Effects of heparosan and heparin on the adhesion and biofilm formation of several bacteria in vitro. Carbohydr. Polym. 88, 1288-1292 (2012)

120. Schaffer, J. N. \& Pearson, M. M. Proteus mirabilis and urinary tract infections. Microbiol. Spectr. https://do org/10.1128/microbiolspec.UTI-0017-2013 (2015).

121. Jacobsen, S. M., Stickler, D. J., Mobley, H. L. T. \& Shirtliff, M. E. Complicated catheter-associated urinary tract infections due to Escherichia coli and Proteus mirabilis. Clin. Microbiol. Rev. 21, 26-59 (2008).

122. Hung, E. W., Darouiche, R. O. \& Trautner, B. W. Proteus bacteriuria is associated with significant morbidity in spinal cord injury. Spinal Cord $\mathbf{4 5}$, 616-620 (2007).

123. Armbruster, C. E. \& Mobley, H. L. T. Merging mythology and morphology: the multifaceted lifestyle of Proteus mirabilis. Nat. Rev. Microbiol. 10 743-754 (2012)

124. Coker, C., Poore, C. A., Li, X. \& Mobley, H. L. T. Pathogenesis of Proteus mirabilis urinary tract infection. Microb. Infect. 2, 1497-1505 (2000).

125. Jones, B. D. \& Mobley, H. L. Genetic and biochemical diversity of ureases of Proteus, Providencia, and Morganella species isolated from urinary tract infection. Infect. Immun. 55, 2198-2203 (1987).

126. Jones, B. V., Young, R., Mahenthiralingam, E. \& Stickler, D. J. Ultrastructure of Proteus mirabilis swarmer cell rafts and role of swarming in catheter-associated urinary tract infection. Infect. Immun 72, 3941-3950 (2004).

127. Mah, T.-F. C. \& O’Toole, G. A. Mechanisms of biofilm resistance to antimicrobial agents. Trends Microbiol. 9, 34-39 (2001)

128. Thomen, P. et al. Bacterial biofilm under flow: first a physical struggle to stay, then a matter of breathing. PLOS ONE 12, e0175197 (2017).

129. Edin-Liljegren, A., Hedelin, H. H., Grenabo, L. \& Pettersson, S. Impact of Escherichia coli on urine citrate and urease-induced crystallization. Scanning Microsc. 9, 901-905 (1995).

130. Bazin, D. et al. Absence of bacterial imprints on struvite-containing kidney stones: a structural investigation at the mesoscopic and atomic scale. Urology 79, 786-790 (2012).

131. Carpentier, X. et al. Relationships between carbonation rate of carbapatite and morphologic characteristics of calcium phosphate stones and etiology. Urology 73, 968-975 (2009).

132. Hesse, A. \& Heimbach, D. Causes of phosphate stone formation and the importance of metaphylaxis by urinary acidification: a review. World J. Urol. 17 308-315 (1999)

133. Cohen, M. S., Warren, M. M., Baur, P., Vogel, J. J. \& Davis, C. P. Intracellular crystal formation in bacteria from human urines: a contributing factor in urinary calculi. Urol. Res. 9, 55-61 (1981).

134. Stewart, P. S. \& Franklin, M. J. Physiological heterogeneity in biofilms. Nat. Rev. Microbiol. 6, 199 (2008).

135. Marcus, R. J. et al. Biofilms in nephrology. Expert Opin. Biol. Ther. 8, 1159-1166 (2008).

136. Tenke, P. et al. Update on biofilm infections in the urinary tract. World J. Urol. 30, 51-57 (2012).

137. Jacobsen, S. M. \& Shirtliff, M. E. Proteus mirabilis biofilms and catheter-associated urinary tract infections. Virulence 2, 460-465 (2011).

138. Flannigan, R., Choy, W. H., Chew, B. \& Lange, D. Renal struvite stones - pathogenesis, microbiology, and management strategies. Nat. Rev. Urol. 11, 333-341 (2014).

139. Flemming, H.-C. \& Wingender, J. The biofilm matrix. Nat. Rev. Micro. 8, 623-633 (2010).

140. An, Y. H. \& Friedman, R. J. Concise review of mechanisms of bacterial adhesion to biomaterial surfaces. J. Biomed. Mat. Res. 43, 338-348 (1998).

141. Zunino, P. et al. Proteus mirabilis fimbriae (PMF) are important for both bladder and kidney colonization in mice. Microbiology 149, 3231-3237 (2003)

142. O’Toole, G., Kaplan, H. B. \& Kolter, R. Biofilm formation as microbial development. Annu. Rev. Microbiol. 54, 49-79 (2000).

143. More, T. T., Yadav, J. S. S., Yan, S., Tyagi, R. D. \& Surampalli, R. Y. Extracellular polymeric substances of bacteria and their potential environmental applications. J. Environ. Manage. 144, 1-25 (2014).

144. O'May, C., Amzallag, O., Bechir, K. \& Tufenkji, N. Cranberry derivatives enhance biofilm formation and transiently impair swarming motility of the uropathogen Proteus mirabilis HI4320. Can. J. Microbiol. 62, 464-474 (2016).
145. Li, X. et al. Spatial patterns of carbonate biomineralization in biofilms. Appl. Environ. Microbiol. 81, 7403-7410 (2015)

146. Li, X., Lu, N., Brady, H. R. \& Packman, A. I. Ureolytic biomineralization reduces Proteus mirabilis biofilm susceptibility to ciprofloxacin. Antimicrob. Agents Chemother. 60, 2993-3000 (2016).

147. Brisbane, W., Bailey, M. R. \& Sorensen, M. D. An overview of kidney stone imaging techniques. Nat. Rev. Urol. 13, 654-662 (2016).

148. Westphalen, A. C., Hsia, R. Y., Maselli, J. H., Wang, R. $\&$ Gonzales, R. Radiological imaging of patients with suspected urinary tract stones: national trends, diagnoses, and predictors. Acad. Emerg. Med. 18 699-707 (2011).

149. Weisenthal, K. et al. Evaluation of kidney stones with reduced-radiation dose CT: progress from 2011-2012 to 2015-2016 - not there yet. Radiology 286, 581-589 (2018)

150. Niemann, T., Kollmann, T. \& Bongartz, G. Diagnostic performance of low-dose CT for the detection of urolithiasis: a meta-analysis. Am. J. Roentgenol. 191 , 396-401 (2008)

151. Smith-Bindman, R. et al. Ultrasonography versus computed tomography for suspected nephrolithiasis. N. Engl. J. Med. 371, 1100-1110 (2014).

152. Ibrahim, E.-S. H. et al. Detection of different kidney stone types: an ex vivo comparison of ultrashort echo time MRI to reference standard CT. Clin. Imaging 40, 90-95 (2016).

153. Tonannavar, J. et al. Identification of mineral compositions in some renal calculi by FT Raman and IR spectral analysis. Spectrochim. Acta A 154, 20-26 (2016).

154. Kasidas, G. P., Samuell, C. T. \& Weir, T. B. Renal stone analysis: why and how? Ann. Clin. Biochem. 41 91-97 (2004).

155. Ghosh, S., Basu, S., Chakraborty, S. \& Mukherjee, A. K. Structural and microstructural characterization of human kidney stones from eastern India using IR spectroscopy, scanning electron microscopy, therma study and X-ray Rietveld analysis. J. Appl. Cryst. 42 629-635 (2009).

156. Charafi, S. et al. A comparative study of two renal stone analysis methods. Int. J. Nephrol. Urol. 2 , 469-475 (2010)

157. Bazin, D., Daudon, M., Combes, C. \& Rey, C. Characterization and some physicochemical aspects of pathological microcalcifications. Chem. Rev. 112, 5092-5120 (2012).

158. Goeres, D. M. et al. Statistical assessment of a laboratory method for growing biofilms. Microbiology 151, 757-762 (2005)

159. Primak, A. N. et al. Noninvasive differentiation of uric acid versus non-uric acid kidney stones using dual-energy CT. Acad. Radiol. 14, 1441-1447 (2007).

160. Haley, W. E. et al. The clinical impact of accurate cystine calculi characterization using dual-energy computed tomography. Case Rep. Radiol. 2015, 5 (2015).

161. Zarse, C. A. et al. Nondestructive analysis of urinary calculi using micro computed tomography. BMC Urol. 4, 15 (2004)

162. Williams, J. C., McAteer, J. A., Evan, A. P. \& Lingeman, J. E. Micro-computed tomography for analysis of urinary calculi. Urol. Res. 38, 477-484 (2010).

163. Gonzalez, R. D., Whiting B. M. \& Canales, B. K. The history of kidney stone dissolution therapy: 50 years of optimism and frustration with renacidin. $J$. Endourol. 26, 110-118 (2012)

164. Wall, I. \& Tiselius, H. G. Long-term acidification of urine in patients treated for infected renal stones. Urol. Int. 45, 336-341 (1990).

165. Stock, I. Natural antibiotic susceptibility of Proteus spp., with special reference to $P$. mirabilis and $P$ penneri strains. J. Chemother. 15, 12-26 (2003).

166. Assimos, D. et al. Surgical management of stones: American Urological Association/Endourological Society Guideline, part I. J. Urol. 196, 1153-1160 (2016).

167. Clatworthy, A. E., Pierson, E. \& Hung, D. T. Targeting virulence: a new paradigm for antimicrobial therapy. Nat. Chem. Biol. 3, 541-548 (2007).

168. Armbruster, C. E., Hodges, S. A. \& Mobley, H. L. T. Initiation of swarming motility by Proteus mirabilis occurs in response to specific cues present in urine and requires excess I-glutamine. J. Bacteriol. 195 1305-1319 (2013).

169. Torzewska, A. \& Rozalski, A. Inhibition of crystallization caused by Proteus mirabilis during the development of infectious urolithiasis by various phenolic substances. Microbiol. Res. 169, 579-584 (2014).

170. Hassan, S. T. S. \& Žemlicka, M. Plant-derived urease inhibitors as alternative chemotherapeutic agents. Arch. Pharm. 349, 507-522 (2016).

171. Pearle, M. S. et al. Medical management of kidney stones: AUA guideline. J. Urol. 192, 316-324 (2014).

172. Pareek, G., Armenakas, N. A., Panagopoulos, G., Bruno, J. J. \& Fracchia, J. A. Extracorporeal shock wave lithotripsy success based on body mass index and Hounsfield units. Urology 65, 33-36 (2005).

173. El-Nahas, A. R., El-Assmy, A. M., Mansour, O. $\&$ Sheir, K. Z. A prospective multivariate analysis of factors predicting stone disintegration by extracorporeal shock wave lithotripsy: the value of high-resolution noncontrast computed tomography. Eur. Urol. 51, 1688-1694 (2007).

174. Messaoudi, N. et al. Prediction of successful treatment by extracorporeal shock wave lithotripsy based on crystalluria-composition correlations of urinary calculi. Asian Pac. J. Trop. Dis. 5, 987-992 (2015).

175. Harmon, W. J., Sershon, P. D., Blute, M. L., Patterson, D. E. \& Segura, J. W. Ureteroscopy: current practice and long-term complications. J. Urol. 157, 28-32 (1997).

176. Wollin, T. A. \& Denstedt, J. D. The Holmium laser in urology. J. Clin. Laser Med. Surg. 16, 13-20 (1998).

177. Bader, M. J., Eisner, B., Porpiglia, F., Preminger, G. M \& Tiselius, H.-G. Contemporary management of ureteral stones. Eur. Urol. 61, 764-772 (2012)

178. Ganpule, A. P., Vijayakumar, M., Malpani, A. $\&$ Desai, M. R. Percutaneous nephrolithotomy (PCNL) a critical review. Int. J. Surg. 36 (Suppl. D), 660-664 (2016).

179. Rassweiler, J., Rassweiler, M. C. \& Klein, J. New technology in ureteroscopy and percutaneous nephrolithotomy. Curr. Opin. Urol. 26, 95-106 (2016).

180. Zhu, W. et al. Minimally invasive versus standard percutaneous nephrolithotomy: a meta-analysis. Urolithiasis 43, 563-570 (2015)

181. Desai, J. et al. A novel technique of ultra-minipercutaneous nephrolithotomy: introduction and an initial experience for treatment of upper urinary calcul less than $2 \mathrm{~cm}$. Biomed Res. Int. 2013, 490793 (2013).

182. Kang, S. K. et al. Systematic review and meta-analysis to compare success rates of retrograde intrarenal surgery versus percutaneous nephrolithotomy for renal stones $>2 \mathrm{~cm}$ : an update. Medicine 96, e9119 (2017).

183. Mitropoulos, D. et al. Reporting and grading of complications after urologic surgical procedures: an ad hoc EAU Guidelines panel assessment and recommendations. Eur. Urol. 61, 341-349 (2012).

184. de la Rosette, J. et al. The clinical research office of the endourological society percutaneous nephrolithotomy global study: indications, complications, and outcomes in 5803 patients. J. Endourol. 25, 11-17 (2011).

185. Assimos, D. G. Anatrophic nephrolithotomy. Urology 57, 161-165 (2001)

186. Keshavamurthy, R. et al. Anatrophic nephrolithotomy in the management of large staghorn calculi - a single centre experience. J. Clin. Diagn. Res. 11, PC01-PC04 (2017).

187. Zhao, J., Ren, L., Zhang, B., Cao, Z. \& Yang, K. In vitro study on infectious ureteral encrustation resistance of Cu-bearing stainless steel. J. Mat. Sci. Technol. 33 1604-1609 (2017).

188. Tunney, M. M., Keane, P. F., Jones, D. S. \& Gorman, S. P. Comparative assessment of ureteral stent biomaterial encrustation. Biomaterials 17 1541-1546 (1996)

189. Gilmore, B. F., Hamill, T. M., Jones, D. S. \& Gorman, S. P. Validation of the CDC biofilm reactor as a dynamic model for assessment of encrustation formation on urological device materials. J. Biomed. Mater. Res. B 93, 128-140 (2010)

190. Gultekinoglu, M. et al. Polyethyleneimine brushes effectively inhibit encrustation on polyurethane ureteral stents both in dynamic bioreactor and in vivo. Mater. Sci. Eng. C 71, 1166-1174 (2017).

191. Gorman, S. P., Garvin, C. P., Quigley, F. \& Jones, D. S. Design and validation of a dynamic flow model simulating encrustation of biomaterials in the urinary tract. J. Pharm. Pharmacol. 55, 461-468 (2003). 
192. Hobbs, T., Schultz, L. N., Lauchnor, E. G., Gerlach, R. \& Lange, D. Evaluation of biofilm induced urinary infection stone formation in a novel laboratory model system. J. Urol. 199, 178-185 (2018).

193. Steefel, C. I., DePaolo, D. J. \& Lichtner, P. C. Reactive transport modeling: an essential tool and a new research approach for the Earth sciences. Earth Planet. Sci. Lett. 240, 539-558 (2005).

194. Connolly, J. M., Jackson, B., Rothman, A. P., Klapper, I. \& Gerlach, R. Estimation of a biofilm-specific reaction rate: kinetics of bacterial urea hydrolysis in a biofilm. NPJ Biofilms Microbiomes 1, 15014 (2015).

195. Morris, N. S., Stickler, D. J. \& McLean, R. J. The development of bacterial biofilms on indwelling urethra catheters. World J. Urol. 17, 345-350 (2000).

196. Parkhurst, D. L. \& Appelo, C. A. J. User's guide to PHREEOC (version 2): report 99-4259 (US Geological Survey, 1999).

197. Gustafsson, J. P. Visual MINTEQ3.1. KTH https:// vminteq. Iwr.kth.se (2000)

198. Brown, C. M., Purich, D. L. \& Ackermann, D. K. EQUIL 93: a tool for experimental and clinical urolithiasis Urol. Res. 22, 119-126 (1994).

199. Nardi, A., Idiart, A., Trinchero, P., de Vries, L. M. \& Molinero, J. Interface COMSOL-PHREEOC (iCP), an efficient numerical framework for the solution of coupled multiphysics and geochemistry. Comput. Geosci. 69, 10-21 (2014).

200. Finlayson, B. Physicochemical aspects of urolithiasis. Kidney Int. 13, 344-360 (1978).

201. Cohen, N. P. \& Whitfield, H. N. Mechanical testing of urinary calculi. World J. Urol. 11, 13-18 (1993).

202. Olszynski, M., Prywer, J. \& Mielniczek- Brzóska, E. Inhibition of struvite crystallization by tetrasodium pyrophosphate in artificial urine: chemical and physical aspects of nucleation and growth. Cryst. Growth Des. 16, 3519-3529 (2016).

203. Chauhan, C. K., Joshi, M. J. \& Vaidya, A. D. B. Growth inhibition of struvite crystals in the presence of herbal extract Commiphora wightii. J. Mater. Sci. Mater. Med. 20, 85 (2008).
204. Chauhan, C. K. \& Joshi, M. J. In vitro crystallization, characterization and growth-inhibition study of urinary type struvite crystals. J. Cryst. Growth 362, 330-337 (2013).

205. Muryanto, S., Sutanti, S. \& Kasmiyatun, M. Inhibition of struvite crystal growth in the presence of herbal extract Orthosiphon aristatus BL.MIO. MATEC Web Conf. 58, 01013 (2016).

206. Basavaraj, D. R., Biyani, C. S., Browning, A. J. \& Cartledge, J. J. The role of urinary kidney stone inhibitors and promoters in the pathogenesis of calcium containing renal stones. EAU-EBU Upd. Series 5, 126-136 (2007).

207. Rajasekharan, S. K., Ramesh, S., Bakkiyaraj, D., Elangomathavan, R. \& Kamalanathan, C.

Burdock root extracts limit quorum-sensingcontrolled phenotypes and biofilm architecture in major urinary tract pathogens. Urolithiasis $\mathbf{4 3}$ 29-40 (2015)

208. Salini, R., Sindhulakshmi, M., Poongothai, T. \& Pandian, S. K. Inhibition of quorum sensing mediated biofilm development and virulence in uropathogens by Hyptis suaveolens. Antonie Van Leeuwenhoek 107 1095-1106 (2015)

209. Younis, K. M., Usup, G. \& Ahmad, A. Secondary metabolites produced by marine streptomyces as antibiofilm and quorum-sensing inhibitor of uropathogen Proteus mirabilis. Environ. Sci. Pollut. Res. 23, 4756-4767 (2016).

210. Salini, R. \& Pandian, S. K. Interference of quorum sensing in urinary pathogen Serratia marcescens by Anethum graveolens. Pathog. Dis. 73, ftv038 (2015).

211. Kazemian, H. et al. Antibacterial, anti-swarming and anti-biofilm formation activities of Chamaemelum nobile against Pseudomonas aeruginosa. Rev. Soc. Bras. Med. Trop. 48, 432-436 (2015).

212. Ranjbar-Omid, M. et al. Allicin from garlic inhibits the biofilm formation and urease activity of Proteus mirabilis in vitro. FEMS Microbiol. Lett. 362, fnv049 (2015).
Acknowledgements

The authors acknowledge the support by the Montana University System Research Initiative (grant 51040MUSRI2015-03) and the Burroughs Wellcome Fund (grant \#1017519). The authors also thankfully acknowledge the helpful comments of three anonymous reviewers.

\section{Author contributions}

All authors researched data for the article, made substantial contributions to discussion of the article contents, wrote the manuscript, and reviewed and/or edited the manuscript before submission.

\section{Competing interests}

The authors declare no competing interests.

Publisher's note

Springer Nature remains neutral with regard to jurisdictional claims in published maps and institutional affiliations.

\section{Review criteria}

A review of the literature was performed by conducting searches in the Web of Science database (until March 2018). Search terms included "kidney/urinary stones", "kidney/urinary stone characterization", "kidney/urinary stone matrix", "kidney/urinary stone biomineralization", "mechanisms of kidney/urinary stone formation", "management of kidney/ urinary stones", "mechanisms of resistance biofilm", and "Proteus mirabilis". No restriction on date of publication was used. The references of recent review articles were also searched to identify key studies related to urinary stones in the areas of chemistry, engineering, mineralogy, microbiology, and medicine. Additional papers were included based on recommendations by the peer reviewers.

\section{RELATED LINKS}

MINTEQ: https://vminteq.lwr.kth.se

PHREEQC: https://wwwbrr.cr.usgs.gov/projects/GWC

coupled/phreeqc

COMSOL: https://www.comsol.com 